University of Szeged

Faculty of Pharmacy

Department of Pharmacodynamics and Biopharmacy

\title{
CHARACTERIZATION OF ANTIPROLIFERATIVE ACTIVITIES OF TRIAZOLYL-STEROID DERIVATIVES
}

PhD Thesis

Judit Molnár

Supervisor:

Dr. habil. István Zupkó Ph.D. 


\section{SCIENTIFIC PUBLICATIONS RELATED TO THE SUBJECT OF THE THESIS}

I. Frank É, Molnár J, Zupkó I, Kádár Z, Wölfling J: Synthesis of novel steroidal 17 $\alpha-$ triazolyl derivatives via $\mathrm{Cu}(\mathrm{I})$-catalyzed azide-alkyne cycloaddition, and an evaluation of their cytotoxic activity in vitro. Steroids 76: 1141-8 (2011)

II. Kádár Z, Molnár J, Schneider G, Zupkó I, Frank É: A facile 'click' approach to novel $15 \beta$-triazolyl- $5 \alpha$-androstane derivatives, and an evaluation of their antiproliferative activities in vitro. Bioorg Med Chem 20: 1396-402 (2012)

III. Molnár J, Frank É, Minorics R, Kádár Z, Ocsovszki I, Schönecker B, Wölfling J, Zupkó I: A click approach to novel D-ring-substituted $16 \alpha$-triazolylestrone derivatives and characterization of their antiproliferative properties. PLOS ONE 10: e0118104 (2015)

\section{ADDITIONAL PUBLICATIONS}

I. Molnár J, Ocsovszki I, Puskás L, Ghane T, Hohmann J, Zupkó I: Investigation of the antiproliferative action of the quinoline alkaloids kokusaginine and skimmianine on human cell lines. Curr Signal Transduct Ther 8: 148-55 (2013)

II. Zupkó I, Molnár J, Réthy B, Minorics R, Frank É, Wölfling J, Molnár J, Ocsovszki I, Topcu Z, Bitó T, Puskás GL: Anticancer and multidrug resistance-reversal effects of solanidine analogs synthetized from pregnadienolone acetate. Molecules 19: 2061-76 (2014)

III. Hajdú Z, Hohmann J, Forgo P, Máthé I, Molnár J, Zupkó I: Antiproliferative activity of Artemisia asiatica extract and its constituents on human tumor cell lines. Planta Med 80: $1692-7$ (2014)

IV. Csupor-Löffler B, Zupkó I, Molnár J, Forgo P, Hohmann J: Bioactivity-guided isolation of antiproliferative compounds from the roots of Onopordum acanthium. Nat Prod Commun 9: 337-40 (2014) 


\section{TABLE OF CONTENTS}

SCIENTIFIC PUBLICATIONS RELATED TO THE SUBJECT OF THE THESIS 2

LIST OF ABBREVIATIONS

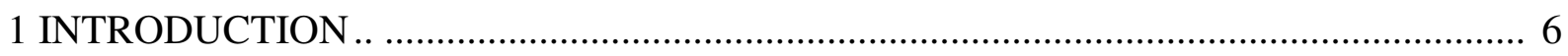

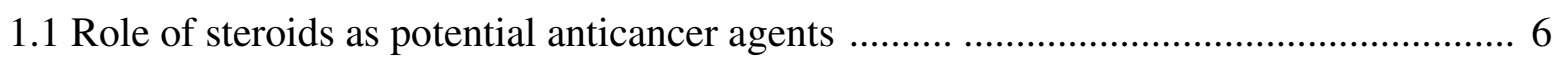

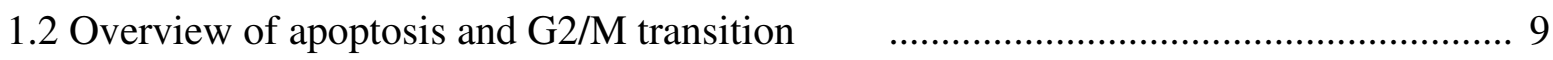

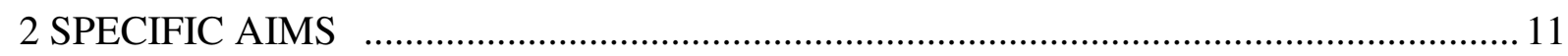

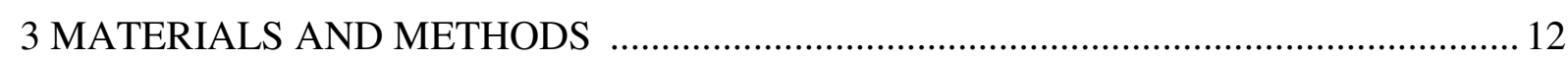

3.1 Chemical structures of novel, D-ring substituted steroid derivatives containing

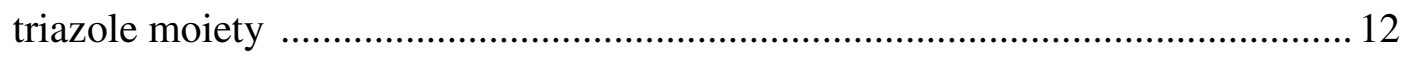

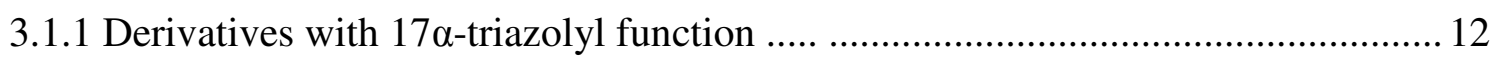

3.1.2 15 $\beta$-Triazolyl derivatives with $5 \alpha$-androstane skeleton .................................. 13

3.1.3 16-Triazolyl derivatives with estrone skeleton ................................................ 13

3.2 Tumor cell lines and cell culture ........................................................................ 14

3.3 Determination of antiproliferative effects of the tested compounds ............................ 15

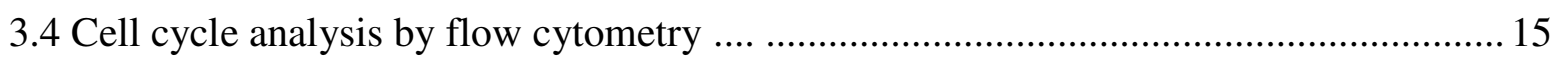

3.5 Double staining with Hoechst 33258 and PI ........................................................ 16

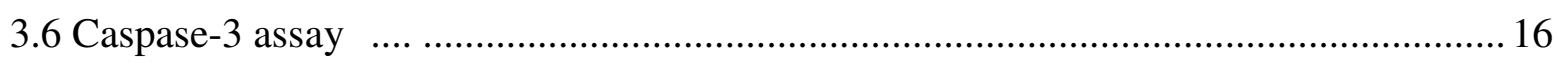

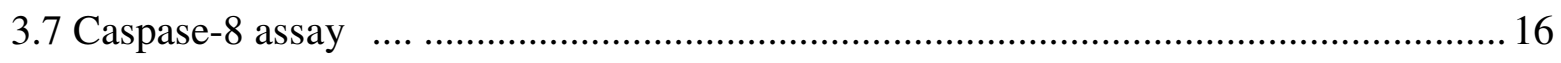

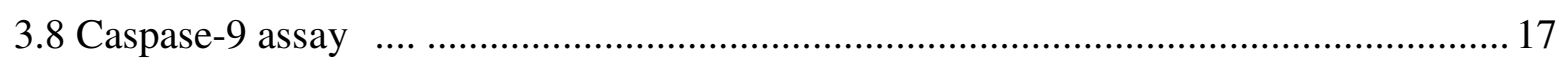

3.9 Reverse transcription-polymerase chain reaction (RT-PCR) studies ......................... 17

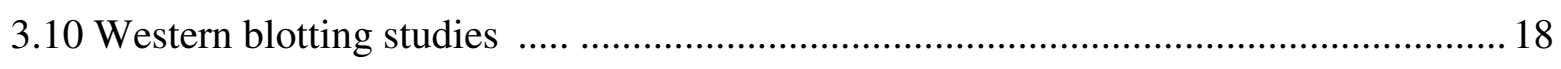

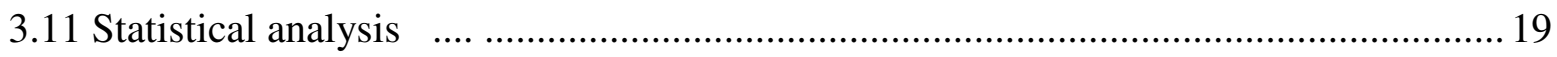


4.1 Antiproliferative properties of $17 \alpha$-triazolyl derivatives .............................................20

4.1.1 Determination of the antiproliferative effects of $17 \alpha$-triazolyl derivatives ...........20

4.2 Antiproliferative properties of $15 \beta$-triazolyl-5 $\alpha$-androstanes ......................................2 22

4.2.1 Determination of the antiproliferative effects of $15 \beta$-triazolyl-5 $\alpha$-androstanes .... 22

4.2.2 Effects of $15 \beta$-triazolyl-5 $\alpha$-androstanes on cell cycle ....................................... 23

4.2.3 Morphological studies with $15 \beta$-triazolyl-5 $\alpha$-androstanes ............................... 25

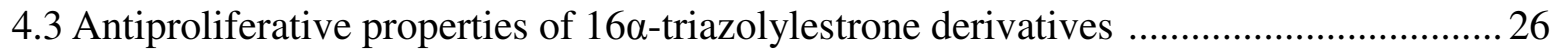

4.3.1 Determination of the antiproliferative effects of $16 \alpha$-triazolylestrone derivatives 26

4.3.2 Effects of $16 \alpha$-triazolylestrone derivatives on cell cycle ..................................29

4.3.3 Morphological studies with $16 \alpha$-triazolylestrone derivatives ............................ 31

4.3.4 Caspase-3, caspase-8 and caspase-9 assays ................................................... 34

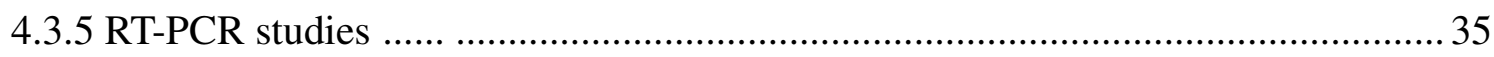

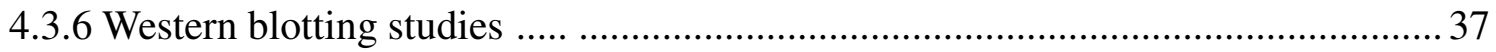

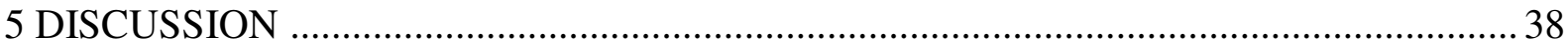

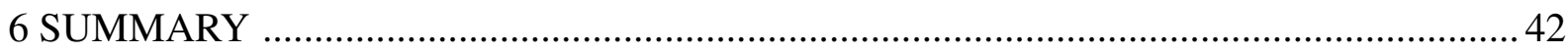

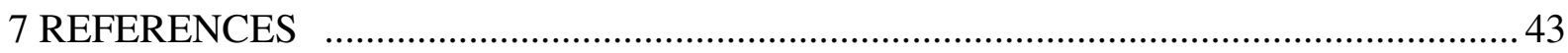

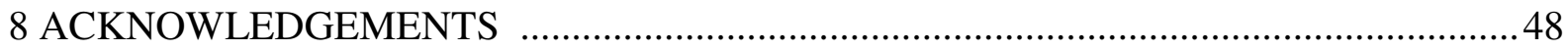




\section{LIST OF ABBREVIATIONS}

Ac-DEVD-pNA

Ac-IETD-pNA

Ac-LEHD-pNA

AIs

ANOVA

ATM

ATR

Bax

Bcl-2

Bp

CDK1

Cdc25

cDNA

DMSO

DNA

dNTP

ER

FBS

hGAPDH

HO

kDa

MMLV-RT

mRNA

MTT

PBS

PI

pNA

RNA

RT-PCR

SEM

SERMs

SERDs

2ME
acetyl-Asp-Glu-Val-Asp-p-nitroanilide

acetyl-Ile-Glu-Thr-Asp-p-nitroaniline

acetyl-Leu-Glu-His-Asp-p-nitroaniline

aromatase inhibitors

analysis of variance

ataxia telangiectasia mutated

ataxia telangiectasia and $\operatorname{Rad} 3$ related

Bcl-2-associated X protein

B-cell lymphoma 2

base pair

cyclin-dependent kinase 1

cell-division cycle protein 25

copy deoxyribonucleic acid

dimethyl sulfoxide

deoxyribonucleic acid

deoxynucleotide triphosphate

estrogen receptor

foetal bovine serum

human glyceraldehydes-3-phosphate dehydrogenase

Hoechst 33258

kilodalton

Moloney murine leukaemia virus-reverse transcriptase

messenger ribonucleic acid

3-(4,5-dimethylthiazol-2-yl)-2,5-diphenyltetrazolium bromide phosphate-buffered saline

propidium iodide

$p$-nitroaniline

ribonucleic acid

reverse transcriptase-polymerase chain reaction

standard error of the mean

selective estrogen receptor modulators

selective estrogen receptor down-regulators

2-methoxyestradiol 


\section{INTRODUCTION}

Since cancerous disorders are the second leading cause of death worldwide, following cardiovascular diseases, improvement of the efficacy of their treatment is currently one of the greatest challenges. A survey of epidemiological data from 184 countries suggested that the global burden of cancer will increase to 23.6 million new cases each year by 2030, an increase of $68 \%$ compared with 2012 (Bray et al., 2012).

\subsection{Role of steroids as potential anticancer agents}

Steroids are a group of endogenous compounds that play versatile roles as anticancer agents. In hormone-dependent tumors such as breast, uterine, ovarian, prostate and endometrial cancers, the overexpression of steroid receptors is involved in enhanced cell proliferation. Different approaches have been devised to reduce the growth-stimulating hormonal response of such cancer cells. Enzyme inhibitors reduce the biosynthesis of endogenous hormones such as steroid sulfatase inhibitors, aromatase inhibitors (AIs) and 17 $\beta$ hydroxysteroid dehydrogenase inhibitors, and ligands compete with endogenous hormones for estrogen receptor (ER) such as antiestrogens. These compounds are classified as steroidal antihormonal/antiproliferative anticancer agents. Nowadays the following agents are used as anti-estrogen therapy such as selective estrogen-receptor modulators (SERMs): tamoxifen, selective estrogen-receptor downregulators (SERDs): fulvestrant and aromatase inhibitors: anastrozole, letrozole and exemestane. Tamoxifen, a non-steroidal agent and a most used antiestrogen in the therapy of breast cancer, binds to the estrogen receptor and acts as an estrogenic and anti-estrogenic agent depending on the origin of the organ. It has an estrogen antagonist effect in breast and an estrogen agonist effect in bone and endometrium. The anticancer effect of this agent depends on the amount of the ER. The selective estrogenreceptor down-regulator fulvestrant is a pure antiestrogen that binds to the ER and inhibits its dimerization and increases its degradation because of the long side chain at the $7 \alpha$ position. AIs are a class of drugs that inhibit the aromatase enzyme, which is responsible for the conversion of androstenedione and testosterone to estrogens, estrone and estradiol. These drugs can be classified as first- (aminoglutetimid), second- (formestan), and third generation (anastrozol, letrozol, exemestan) AIs, or according to the mechanism of action they can be also classified as type 1 (steroidal AIs) and type 2 (non-steroidal AIs) AIs. Type 1 AIs such as formestane and exemestane are steroidal analogs of androstenedione and bind irreversibly to 
the aromatase enzyme but type 2 AIs have a non-steroidal structure and bind reversibly to the aromatase enzyme (Brunton et al., 2011).

Additionally, a broad variety of steroidal molecules have either been isolated from natural sources or rationally designed and synthetized, and have been reported to exhibit efficacy against cancer cells through nonhormonal mechanisms. Cytotoxic steroids exert their actions on various molecular targets (e.g. microtubules or topoisomerase), usually leading to cell cycle blockade and apoptosis (Gupta et al., 2013).

Estrogens are widely recognised as factors for tumor growth, mainly in breast cancer. The natural product 2-methoxyestradiol $(2 \mathrm{ME})$ is a major estradiol metabolite, the process of the metabolism of estradiol is the same in males and females and it is catalysed by catechol$O$-methyltransferase. 2ME has no estrogenic activity and numerous studies showed its anticancer properties (antiproliferative, proapoptotic and cytotoxic activities) and possible cardiovascular benefits. The mechanism of action of $2 \mathrm{ME}$ is based on the inhibition of tubulin polymerization. $2 \mathrm{ME}$ has been tested in clinical setting but it has a short half-life and poor bioavailability and is not optimal for direct drug development, which indicates the modifications of the pharmacokinetic profile of the parent compound and the introduction of novel synthetic 2ME analogues (Peyrat et al., 2012).

Plants are among the most varied and promising sources of new anticancer agents and steroids can also be found in them. Natural products are playing a rapidly increasing role in finding new lead candidates for the development of chemotherapeutic agents. They offer a valuable source of compounds with a wide variety of chemical structures with biological activities, and provide important prototypes for the development of novel drugs. Cardiac glycosides are natural steroids, derived from digitalis species. Cardiotonic steroids contain three structural elements: a steroid nucleus, an unsaturated lactone and a carbohydrate. The main cardiac effects of cardenolides are mediated through inhibition of the sodium potassium ATPase that results in increased contractility of cardiac myocytes. Cardiac glycosides like digoxin and digitoxin have been used in the treatment of atrial fibrillation, some types of heart failure and supraventricular tachycardia. Besides the cardiologic activities of digitoxin and digoxin, these steroids also have an anticancer activity. In recent years, additional effects of cardiac glycosides on cancer cells have been described. Cardenolides also have well known antiproliferative effects on tumor cells. Non-toxic concentrations of digitoxin and digoxin inhibit growth and induce apoptosis in different human malignant cell lines, whereas highly proliferating normal cells are not affected. Although these compounds have no use as 
anticancer agents because of the cardiac side effects, the structure of these compounds can be used for the development of novel anticancer agents (Mijatovic and Kiss, 2013).

Different analogs of estrone and androstane derivatives modified in D-ring were tested in the Department of Pharmacodynamics and Biopharmacy, University of Szeged. The antiproliferative effects of D-homo- and D-secoestrones, normal and 13-epi-D-homoestrone and their 3-methyl ethers, estrone-16-oxime ethers and steroidal 17-2'-(1',3',4')-oxadiazoles were tested on human cancer cell lines in vitro. These compounds have antiproliferative activities on cancer cell lines, induce apoptosis and disturbance in cell cycle and show selective toxicity as evidenced by means of testing them on MRC5 cell line (Minorics et al., 2012, Berényi et al., 2013, Kovács et al., 2014, Mernyák et al., 2014).

Based on these preliminary results design, synthesis and investigation of antiproliferative steroidal agents containing triazolyl building blocks have been initiated.

Compounds containing triazole ring represent a wide range of biological and pharmacological properties such as anticancer, antifungal, antibacterial, antitubercular, antiviral, anti-inflammatory and analgesic, anticonvulsant, antiparasitic, antidiabetic, antiobesitic, antihistaminic, anti-neuropathic and antihypertensive properties. The triazole ring can be found in many biologically active compounds used in therapy such as trazodone, rizatriptan, hexaconazole and alprazolam. Most of all triazole derivatives have strong pharmacological activity, high bioavailability and favorable pharmacokinetics property (Buckle et al., 1986, Alvarez et al., 1994, Genin et al., 2000, Zhou and Wang, 2012, Sahu et al., 2013).

The introduction of a triazole ring at position 3 of the natural triterpene betulinic acid resulted in a set of compounds with considerable antiproliferative potency and proapoptotic capacity (Majeed et al., 2013). The introduction of a triazole moiety into the podophyllotoxin skeleton yielded conjugates with significant topoisomerase-II-inhibiting activity, and some of these new compounds proved more potent than the clinically used etoposide (Liu et al., 2013).

The synthesis of steroidal heterocycles has also attracted considerable interest in view of their valuable pharmacological activities (Wölfling et al., 2004, Wölfling et al., 2006). Steroidal azoles have been described as potent inhibitors of $17 \alpha$-hydroxylase- $\mathrm{C}_{17,20}$-lyase (CYP17), which can block androgen synthesis at an early stage, and may therefore be of use in the treatment of prostatic carcinoma (Hofmeister et al., 1992, Brodie and Njar, 1999). Furthermore, some heterocyclic derivatives have been found to exert strong inhibitory effects on $5 \alpha$-reductases (Salvador et al., 2013). 
Banday et al. recently reported the syntheses of some 21-triazoles of pregnenolone as potent anticancer agents through a "click" chemistry approach (Banday et al., 2010). In this regard, we have demonstrated that a number of triazolyl androstanes can exert direct cytostatic effects on human cancer cell lines in vitro (Kádár et al., 2011a, Kádár et al., 2011b). Although the introduction of substituted triazole rings at position 17 of the estrane skeleton has so far met with only limited success as concerns the antiproliferative activity, the synthetic modification of compounds in the estrone series still seems to provide excellent possibilities in the search for novel derivatives with noteworthy biological effects (Frank and Schneider, 2013).

A triazole ring has been successfully utilized as a linker for the preparation of estradiol-containing agents based on anticancer natural products. The most active conjugate inhibited the growth of cancer cell lines at submicromolar concentrations, exerted disruption of the microtubule network, and disturbed the cell cycle distribution of MCF7 cells and the induction of apoptosis. These properties were explained by the downregulation of cyclindependent kinase 1 (CDK1) and the upregulation of crucial tumor suppressors (p21 and p53) (Kamal et al., 2011).

\subsection{Overview of apoptosis and G2/M transition}

Apoptosis or programmed cell death is a normal component of the development of a multicellular organism. During apoptosis cells die in a controlled manner and apoptotic cells can be recognized by morphological changes. These changes include blebbing, cell shrinkage, nuclear fragmentation, chromatin condensation and DNA fragmentation and finally the cell fragmented into membrane enclosed structures called apoptotic bodies. In contrast to necrosis, in which uncontrolled cell death leads to cell lysis and inflammatory responses, the apoptotic bodies are engulfed by macrophages and are removed from the tissue without causing an inflammatory response. Apoptosis can be activated by various signals from outside and inside the cell, and caspases play a crucial role in this process. Caspases are proteins that are highly conserved, cysteine-dependent aspartate-specific proteases. Proapoptotic caspases can be divided into two groups, the group of initiator caspases: 2, 8, 9 and 10, and the group of executioner caspases: 3, 6 and 7. Caspase-8 plays a crucial role in the extrinsic pathway of apoptosis, in which the apoptosis inducing signal derives from death receptors. The intrinsic pathway of apoptosis involves caspase-9 apoptosis triggered by signals derived from the mitochondrion. The activation of initiator caspases requires binding to specific activator 
protein. Effector caspases are then activated by these active initiator caspases through proteolytic cleavage for the execution of apoptosis (Kumar, 2007).

The G2/M signalling pathway plays an important role in the cell cycle because this checkpoint regulates the entering of cells to mitosis (M-phase). If the cells have a defective G2/M checkpoint, the cells can enter mitosis before repairing the DNA damage and this leads to uncontrolled cell division with genetic failure. The cell cycle is regulated by cyclins and cyclin dependent kinases (CDKs), and in the case of G2/M checkpoint by the cyclinB-cdc2 (CDK1) complex. The activity of CDK1 is regulated by cyclinB1, cyclinB2 and the phosphorylation of the specific residue is also very important. CDK1 is maintained inactive during most of the cell cycle through phosphorylation by Wee1 and Myt1 kinases. When CDK1 activity becomes required for the progression into the $\mathrm{M}$ phase, cdc25 phosphatase dephosphorylates the CDK1-containing complex. DNA damage leads to ATM/ATR kinase activation, resulting in the inactivation of cyclinB/CDK1 complex through the activity of Chk kinase, which phosphorylates and inactivates cdc25, which has an important role in the activation of CDK1 by dephosphorylation (Boutros et al., 2007). 


\section{SPECIFIC AIMS}

The aim of the present study was to determine the antiproliferative properties of novel, D-ring modified steroid derivatives containing triazole substituent:

2.1 Investigation of antiproliferative effects and determination of structure - activity relationship of newly synthesized estranes or androstanes containing substituted triazole ring at position 15, 16, 17 in vitro using human adherent cancer cell lines.

2.2 The most effective compounds were selected for additional in vitro experiments in order to characterize the possible mechanism of action. These further investigations included cell cycle analysis by flow cytometry, morphological study by fluorescent microscopy after HOPI double staining, caspase-3, -8 and -9 enzyme activity and the expression of cell cycle regulating factors by RT-PCR technique and Western blot study.

2.3 Characterizing the cancer selectivity of the selected agents by determining their action on the viability of human fibroblast. 


\section{MATERIALS AND METHODS}

\subsection{Chemical structures of novel, D-ring substituted steroid derivatives containing}

triazole moiety

\subsubsection{Derivatives with $17 \alpha$-triazolyl function}

The first set of the investigated compounds contained $17 \alpha$-triazolyl steroid analogues. The tested agents possessed estrone or androstane skeleton and in both series a triazole ring was attached to ring $\mathrm{D}$ at position 17. The compounds were substituted with different functions on the triazol ring. All of the investigated compounds were designed and synthetized by the staff in the Institute of Organic Chemistry, University of Szeged.

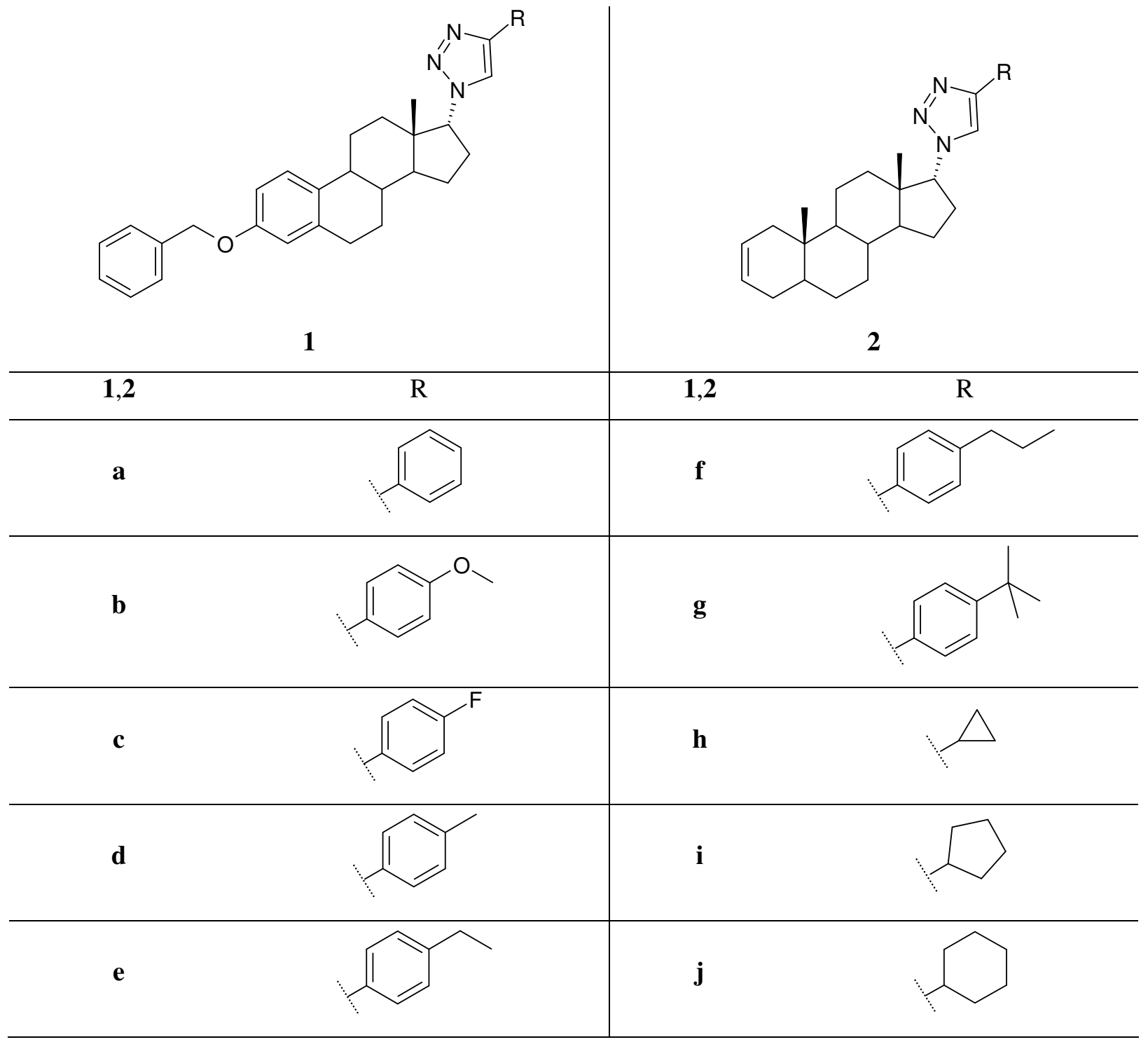

Figure 1. Structures of 17 $\alpha$-triazolyl steroid analogues 


\subsubsection{5 $\beta$-Triazolyl derivatives with $5 \alpha$-androstane skeleton}

The second set of the investigated compounds included $15 \beta$-triazolyl-5 $\alpha$-androstane analogues. The tested agents possessed androstane skeleton in which ring A was substituted with acetoxy functions at position 3 . The differences between the analogues are the $-\mathrm{OH}$ and $=\mathrm{O}$ groups at position 17. A triazol ring was attached to ring $\mathrm{D}$ at position 15 . The compounds were substituted with different functions on the triazol ring.<smiles>[R]c1cn(C2CC(O)C3(C)CCC4C(CCC5CC(OC(C)=O)CCC54C)C23)nn1</smiles>

3<smiles>[R]c1cn(C2CC(=O)C3(C)CCC4C(CCC5CC(OC(C)=O)CCC54C)C23)nn1</smiles>

4

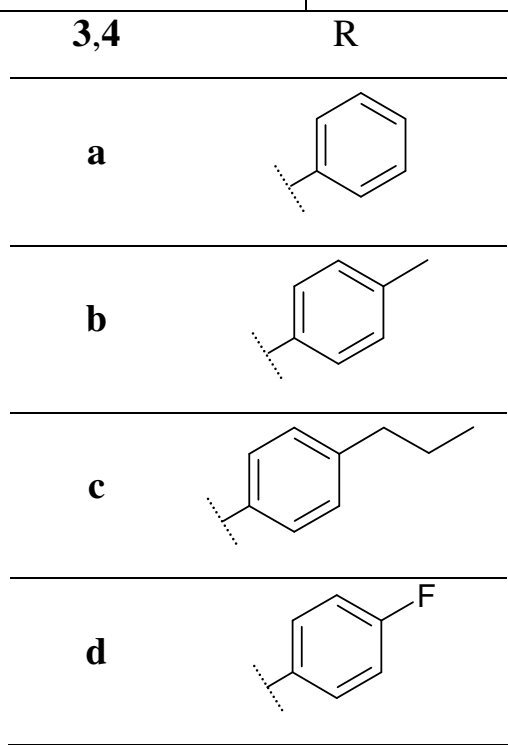

Figure 2. Structures of $15 \beta$-triazolyl-5 $\alpha$-androstane analogues

\subsubsection{6-Triazolyl derivatives with estrone skeleton}

The third set of the investigated compounds was composed of 16-triazolyl estrone epimers. The tested agents possessed estrone skeleton in which ring A was substituted with methoxy function at position 3. A triazol ring was attached to ring $\mathrm{D}$ at position 16 . The compounds were substituted with different functions on the triazole ring. 


(n)

Figure 3. Structures of 16-triazolyl steroid analogues

\subsection{Tumor cell lines and cell culture}

Human cell lines were purchased from ECACC (Salisbury, UK). HeLa (cervix adenocarcinoma), A431 (skin epidermoid carcinoma), MCF7 (breast adenocarcinoma) and noncancerous MRC-5 fetal lung fibroblast cells were cultivated in minimal essential medium supplemented with $10 \%$ fetal bovine serum, $1 \%$ non-essential amino acids and an antibioticantimycotic mixture. All media and supplements were obtained from PAA Laboratories GmbH (Pasching, Austria). 


\subsection{Determination of antiproliferative effects of the tested compounds}

Near-confluent cancer cells were seeded onto a 96-well microplate (5000/well) and attached to the bottom of the well overnight. On the second day, $200 \mu \mathrm{L}$ of new medium containing the tested compound (at 10 or $30 \mu \mathrm{M}$ ) was added. After incubation for $72 \mathrm{~h}$ at $37^{\circ} \mathrm{C}$ in humidified air with $5 \% \mathrm{CO}_{2}$, the living cells were assayed by the addition of $20 \mu \mathrm{L}$ of $5 \mathrm{mg} / \mathrm{mL}$ MTT [3-(4,5-dimethylthiazol-2-yl)-2,5-diphenyltetrazolium bromide] solution. MTT was converted by intact mitochondrial reductase and precipitated as blue crystals during a 4-h contact period. The medium was then removed and the precipitated crystals were dissolved in $100 \mu \mathrm{L}$ of DMSO during a 60-min period of shaking at $25{ }^{\circ} \mathrm{C}$. Finally, the reduced MTT was assayed at $545 \mathrm{~nm}$, using a microplate reader; wells with untreated cells were utilized as controls (Mosmann, 1983). For the most effective compounds, the assays were repeated with a set of dilutions, and sigmoidal dose-response curves were fitted to the measured data in order to determine the $\mathrm{IC}_{50}$ values by means of GraphPad Prism 4.0 (GraphPad Software; San Diego, CA, USA). All in vitro experiments were carried out on two microplates with at least five parallel wells. Cisplatin was used as positive control. Stock solutions of the tested substances $(10 \mathrm{mM})$ were prepared with DMSO. The highest DMSO content of the medium $(0.3 \%)$ did not have any substantial effect on the cell proliferation.

\subsection{Cell cycle analysis by flow cytometry}

Cellular DNA content was determined by means of flow cytometric analysis, using a DNA-specific fluorescent dye, propidium iodide (PI). The cells were plated in a six-well plate and cultured for $24 \mathrm{~h}$. The cultured cells were treated with various concentrations of the tested compounds for 24 or $48 \mathrm{~h}$, after which the medium was removed, and the cells were washed with phosphate-buffered saline (PBS) and trypsinized. The harvested cells were suspended in medium and centrifuged at $1,700 \mathrm{rpm}$ for $15 \mathrm{~min}$ at $4{ }^{\circ} \mathrm{C}$. The supernatant was then removed and the cells were resuspended in $1 \mathrm{~mL}$ of PBS. After the second centrifugation, $1 \mathrm{~mL}$ of -20 ${ }^{\circ} \mathrm{C} 70 \% \mathrm{EtOH}$ was added dropwise to the cell pellet. The cells were stored at $-20{ }^{\circ} \mathrm{C}$ until the day of DNA staining. On the day of DNA staining, the samples were washed with PBS and suspended in $1 \mathrm{~mL}$ of DNA staining buffer containing PI, ribonuclease-A, Triton-X and sodium citrate. After incubation for $1 \mathrm{~h}$ at room temperature, protected from light, the samples were analyzed by FACStar. For each experiment 20,000 events were counted, and the percentages of the cells in the different cell-cycle phases (subG1, G1, S and G2/M) were determined by means of winMDI 2.8 (Vermes et al., 2000). 


\subsection{Double staining with Hoechst 33258 and PI}

Cells were seeded into a 96-well plate and incubated with various concentrations of the tested compounds for $24 \mathrm{~h}$. The medium was then removed and $100 \mu \mathrm{L}$ of medium with $10 \mu \mathrm{L}$ of staining solution was added to the cells. The final concentrations of Hoechst 33258 and PI were 5 and $3 \mu \mathrm{g} / \mathrm{mL}$, respectively. After incubation for $60 \mathrm{~min}$ at $37^{\circ} \mathrm{C}$, the cells were examined on a Nikon Fluorescence Microscope equipped with a Digital Sight Camera System, including appropriate filters for Hoechst 33258 and PI (Ribble et al., 2005, Minorics et al., 2011).

\subsection{Caspase-3 assay}

Caspase-3 activity was determined by using a colorimetric assay kit (Sigma-Aldrich Ltd., Budapest, Hungary), Ac-DEVD- $p$ NA serving as substrate. During the assay, the peptide substrate was cleaved by caspase-3, resulting in the release of $p$ NA ( $p$-nitroaniline), which was measured by a microplate reader at an absorbance wavelength of $405 \mathrm{~nm}$. Caspase-3 activity was determined in the presence and absence of a selective inhibitor for caspase- 3 . HeLa cells were treated with the tested compounds at 3,10 and $30 \mu \mathrm{M}$ for $24 \mathrm{~h}$; untreated cells were used as controls. The treated cells were scraped and incubated on ice with cell lysis buffer in proportion to the cell number for $15 \mathrm{~min}$. The cell lysate was next centrifuged for 15 min at 17,000 $\mathrm{g}$ and the supernatant was collected and assayed by means of the microplate reader. Results were expressed in fold increase of caspase-3 activity compared with the control result (Molnár et al., 2013).

\subsection{Caspase-8 assay}

Caspase- 8 activity was determined by using a colorimetric assay kit (Sigma-Aldrich Ltd., Budapest, Hungary), Ac-IETD- $p$ NA serving as substrate. During the assay, the peptide substrate was cleaved by caspase- 8 , resulting in the release of $p \mathrm{NA}$, which was measured on a microplate reader at an absorbance wavelength of $405 \mathrm{~nm}$. All further conditions were identical with those of the caspase- 3 assay. 


\subsection{Caspase-9 assay}

Caspase-9 activity was determined by using a colorimetric assay kit (Invitrogen; Carlsbad, CA, USA), with Ac-LEHD- $p$ NA as substrate. During the assay the peptide substrate was cleaved by caspase-9, resulting in the release of $p \mathrm{NA}$, which was measured on a microplate reader at an absorbance wavelength of $405 \mathrm{~nm}$. All further conditions were identical with those of the caspase-3 assay.

\subsection{Reverse transcription-polymerase chain reaction (RT-PCR) studies}

The effects of the tested compounds on the mRNA expression pattern of the markers of apoptosis, such as Bax, Bcl-2, cyclin-dependent kinase 1 (CDK1), cdc25B, cyclin B1 and cyclin B2, which play a crucial role in the transition from the G2 to the $M$ phase, were determined by RT-PCR in HeLa cells. After a 24-h incubation period, the total RNA was isolated from the cells $\left(4 \times 10^{5}\right)$ through the use of TRIzol Reagent, in accordance with the instructions of the provider (Csertex Ltd; Budapest, Hungary). The pellet was resuspended in $100 \mu \mathrm{L}$ of DNase- and RNase-free distilled water. The RNA concentrations of the samples were determined from their absorbances at $260 \mathrm{~nm}$. The RNA $(0.5 \mu \mathrm{g})$ was mixed with DNase- and RNase-free distilled water and $20 \mu \mathrm{M}$ oligodT (Invitrogen; Carlsbad, CA, USA), in a final reaction volume of $10 \mu \mathrm{L}$, and the mixture was incubated at $70{ }^{\circ} \mathrm{C}$ for $5 \mathrm{~min}$. After the mixture had been cooled to $4{ }^{\circ} \mathrm{C}, 20 \mathrm{U}$ of RNase inhibitor (Promega, Madison, WI, USA), $20 \mathrm{U}$ of MMLV reverse transcriptase (Promega, Madison, USA), $200 \mu \mathrm{M}$ dNTP (SigmaAldrich; Budapest, Hungary) in $50 \mathrm{mM}$ Tris- $\mathrm{HCl}, \mathrm{pH} 8.3,75 \mathrm{mM} \mathrm{KCl}$ and $5 \mathrm{mM} \mathrm{MgCl}_{2}$ in a final reaction volume of $10 \mu \mathrm{L}$ were added. The mixture was incubated at $37{ }^{\circ} \mathrm{C}$ for $60 \mathrm{~min}$. The PCR was carried out with $5 \mu \mathrm{L}$ of cDNA, $12.5 \mu \mathrm{L}$ of GoTaq Green Master Mix, $2 \mu \mathrm{L}$ of $20 \mathrm{pM}$ sense and the antisense primers of Bax, Bcl-2, CDK1, cdc25B, cyclin B1, cyclin B2 and 3.5 $\mu \mathrm{L}$ of DNase- and RNase-free distilled water. Human glyceraldehyde 3-phosphate dehydrogenase (hGAPDH) primers were used as internal control in all samples (Table 1). The PCR was performed with an ESCO SWIFT MAXI thermal cycler (Esco Technologies; Philadelphia, PA, USA) and the products were separated on $2 \%$ agarose gels, stained with ethidium bromide and photographed under a UV transilluminator. Semiquantitative analysis was performed by densitometric scanning of the gel with a Kodak IMAGE STATION 2000R (Csertex; Budapest, Hungary). 
Table 1. Primers and PCR conditions of the determined genes, the Genebank access numbers and the length of PCR products

\begin{tabular}{|c|c|c|c|c|}
\hline Name: & Primer sequence & Gene ID & $\begin{array}{c}\text { Product } \\
\text { size } \\
\text { (bp) }\end{array}$ & $\begin{array}{c}\text { Coupling } \\
\text { temp. } \\
\left({ }^{\circ} \mathrm{C}\right)\end{array}$ \\
\hline CDK1 & $\begin{array}{l}\text { F: ACTGGCTGATTTTGGCCTTGCC } \\
\text { R: TGAGTAACGAGCTGACCCCAGCAA }\end{array}$ & 983 & 118 & 62 \\
\hline cyclin B1 & $\begin{array}{l}\text { F: AATAAGGAGGGAGCAGTGCG } \\
\text { R: GAAGAGCCAGCCTAGCCTCAG }\end{array}$ & 891 & 51 & 60 \\
\hline cyclin B2 & $\begin{array}{l}\text { F: GCGTTGGCATTATGGATCG } \\
\text { R: TCTTCCGGGAAACTGGCTG }\end{array}$ & 9133 & 51 & 60 \\
\hline Cdc25B & $\begin{array}{l}\text { F: CACGCCCGTGCAGAATAAGC } \\
\text { R: ATGACTCTCTTGTCCAGGCTACAGG }\end{array}$ & 994 & 417 & 60 \\
\hline Bax & $\begin{array}{l}\text { F: TGGCAGCTGACATGTTTTCTGAC } \\
\text { R: CGTCCCAACCACCCTGGTCT }\end{array}$ & 581 & 195 & 53 \\
\hline $\mathrm{Bcl}-2$ & $\begin{array}{l}\text { F: GACTTCGCCGAGATGTCCAG } \\
\text { R: CAGGTGCCGGTTCAGGTACT }\end{array}$ & 596 & 225 & 51 \\
\hline hGAPDH & $\begin{array}{l}\text { F: ACCCAGAAGACTGTGGATGG } \\
\text { R: TGCTGTAGCCAAATTCGTTG }\end{array}$ & 2597 & 415 & 55 \\
\hline
\end{tabular}

\subsection{Western blotting studies}

To investigate the actions of the most potent compounds on the functions of phosphorylated and total stathmin, protein expression was determined by using Western blot analysis. HeLa cells were harvested in $60-\mathrm{mm}$ dishes at a density of $2 \times 10^{5}$ cells $/ \mathrm{mL}$ and treated with the tested agents for $48 \mathrm{~h}$. Whole-cell extracts were prepared by washing the cells with PBS and suspending them in lysis buffer (50 mM Tris, $5 \mathrm{mM}$ EDTA, $150 \mathrm{mM} \mathrm{NaCl}, 1 \%$ NP-40, 0.5\% deoxycholic acid, $1 \mathrm{mM}$ sodium orthovanadate, $100 \mu \mathrm{g} / \mathrm{mL}$ PMSF and protease inhibitors) (Lee et al., 2007). $10 \mu \mathrm{g}$ of protein per well was subjected to electrophoresis on 4 12\% NuPAGE Bis-Tris Gel in XCell SureLock Mini-Cell Units (Invitrogen, Carlsbad, CA, USA). Proteins were transferred from gels to nitrocellulose membranes, using the iBlot Gel Transfer System (Invitrogen, Carlsbad, CA, USA). Antibody binding was detected with the WesternBreeze Chemiluminescent Western blot immunodetection kit (Invitrogen, Carlsbad, CA, USA). The blots were incubated on a shaker with stathmin (Op18: rabbit polyclonal 
antibody raised against amino acids 1-149 representing full-length human protein), phosphorylated stathmin (p-Op18: rabbit polyclonal antibody raised against a short amino acid sequence containing phosphorylated Ser25 of human protein) and $\beta$-actin polyclonal antibody (Santa Cruz Biotechnology, Santa Cruz, CA, USA) 1:200 in the blocking buffer. Each sample was prepared in three parallels and the experiments were repeated twice. Semiquantitative analysis was performed by densitometric scanning of the blot with Kodak IMAGE STATION 2000R (Eastman Kodak Co., Rochester, NY, USA). All determined optical density values were normalized to the optical density value of $\beta$-actin.

\subsection{Statistical analysis}

Statistical analyses were carried out by analysis of variance (ANOVA), followed by the Dunnet post-test. Western blott data were analyzed by ANOVA, followed by the NeumanKeuls post-test using GraphPad Prism version 4.0 for Windows (GraphPad Software, San Diego, CA, USA). 


\section{RESULTS}

\subsection{Antiproliferative properties of $17 \alpha$-triazolyl derivatives}

\subsubsection{Determination of the antiproliferative effects of $17 \alpha$-triazolyl derivatives}

In order to determine the antiproliferative effect of the prepared $17 \alpha$-triazolyl derivatives, the steroids were tested on human cancerous cell lines (HeLa, A431 and MCF7) by means of the MTT assay. Two final concentrations (10 and $30 \mu \mathrm{M})$ were applied for all compounds. The estrone derivatives $(\mathbf{1 a}-\mathbf{j})$ have a moderate effect, these compounds elicited less than $60 \%$ inhibition of cell proliferation even at higher concentration. The corresponding androstane series $(\mathbf{2 a}-\mathbf{j})$ were generally more effective on the cell proliferation (Table 2). Derivatives with an unsubstituted phenyl ring (2a) and those containing simple substituents $(\mathbf{2 b}-\mathbf{c})$ or cycloalkyl groups $(\mathbf{2} \mathbf{i}-\mathbf{j})$ and the introduction of a carbon chain (ethyl) exerted moderate action. However, the extension of the carbon chain on the phenol ring (propyl; 2f) and the introduction of cycloalkyl group (2h) on the aromatic moiety resulted in increased activities. Since most of these analogs exerted a moderate antiproliferative action, no additional experiments were performed. 
Table 2 Antiproliferative properties of $17 \alpha$-triazolyl derivatives

\begin{tabular}{|c|c|c|c|c|}
\hline \multirow{2}{*}{ Compound } & \multirow{2}{*}{$\begin{array}{c}\text { Conc. } \\
(\mu \mathrm{M})\end{array}$} & \multicolumn{3}{|c|}{ Inhibition $\% \pm$ SEM } \\
\hline & & HeLa & MCF7 & A431 \\
\hline \multirow[t]{2}{*}{$1 \mathbf{a}$} & 10 & $<25$ & $<25$ & $34.86 \pm 1.0$ \\
\hline & 30 & $<25$ & $<25$ & $30.2 \pm 1.0$ \\
\hline \multirow[t]{2}{*}{$2 \mathbf{a}$} & 10 & $45.9 \pm 0.8$ & $33.9 \pm 1.3$ & $36.9 \pm 0.9$ \\
\hline & 30 & $72.4 \pm 0.5$ & $47.2 \pm 0.7$ & $58.4 \pm 0.9$ \\
\hline \multirow[t]{2}{*}{$1 b$} & 10 & $28.0 \pm 2.4$ & $<25$ & $43.9 \pm 1.8$ \\
\hline & 30 & $41.2 \pm 1.8$ & $32.6 \pm 1.3$ & $48.3 \pm 2.0$ \\
\hline \multirow[t]{2}{*}{$2 b$} & 10 & $52.0 \pm 1.2$ & $41.8 \pm 1.7$ & $53.1 \pm 1.3$ \\
\hline & 30 & $53.7 \pm 1.4$ & $52.9 \pm 1.6$ & $62.3 \pm 1.6$ \\
\hline \multirow[t]{2}{*}{ 1c } & 10 & $<25$ & $<25$ & $<25$ \\
\hline & 30 & $27.9 \pm 1.9$ & $<25$ & $26.8 \pm 0.9$ \\
\hline \multirow[t]{2}{*}{$2 c$} & 10 & $44.4 \pm 0.3$ & $55.1 \pm 1.4$ & $55.2 \pm 1.7$ \\
\hline & 30 & $62.8 \pm 1.1$ & $78.8 \pm 0.5$ & $75.2 \pm 0.7$ \\
\hline \multirow[t]{2}{*}{ 1d } & 10 & $<25$ & $<25$ & $<25$ \\
\hline & 30 & $36.2 \pm 1.4$ & $27.6 \pm 0.1$ & $34.5 \pm 1.7$ \\
\hline \multirow[t]{2}{*}{ 2d } & 10 & $32.8 \pm 1.8$ & $<25$ & $30.7 \pm 1.4$ \\
\hline & 30 & $53.4 \pm 1.7$ & $39.0 \pm 1.9$ & $48.9 \pm 1.0$ \\
\hline \multirow[t]{2}{*}{$1 e$} & 10 & $<25$ & $<25$ & $<25$ \\
\hline & 30 & $<25$ & $<25$ & $33.5 \pm 2.2$ \\
\hline \multirow[t]{2}{*}{$2 e$} & 10 & $30.0 \pm 0.7$ & $<25$ & $<25$ \\
\hline & 30 & $67.5 \pm 0.7$ & $47.3 \pm 1.6$ & $51.2 \pm 1.5$ \\
\hline \multirow[t]{2}{*}{ 1f } & 10 & $<25$ & $<25$ & $<25$ \\
\hline & 30 & $26.6 \pm 1.8$ & $<25$ & $27.2 \pm 1.9$ \\
\hline \multirow[t]{2}{*}{$2 f$} & 10 & $59.7 \pm 1.0$ & $34.9 \pm 1.6$ & $68.7 \pm 0.8$ \\
\hline & 30 & $78.6 \pm 0.4$ & $53.3 \pm 0.5$ & $81.1 \pm 0.1$ \\
\hline \multirow[t]{2}{*}{$1 \mathrm{~g}$} & 10 & $<25$ & $<25$ & $34.8 \pm 1.9$ \\
\hline & 30 & $<25$ & $<25$ & $29.9 \pm 1.7$ \\
\hline \multirow[t]{2}{*}{$2 \mathrm{~g}$} & 10 & $27.0 \pm 0.7$ & $<25$ & $30.5 \pm 1.4$ \\
\hline & 30 & $46.1 \pm 0.9$ & $30.4 \pm 1.7$ & $48.2 \pm 0.6$ \\
\hline \multirow[t]{2}{*}{$1 \mathrm{~h}$} & 10 & $47.0 \pm 1.8$ & $34.6 \pm 1.5$ & $47.8 \pm 1.9$ \\
\hline & 30 & $43.2 \pm 2.0$ & $41.9 \pm 1.0$ & $49.8 \pm 2.0$ \\
\hline $2 \mathrm{~h}$ & 10 & $52.4 \pm 1.4$ & $30.4 \pm 1.9$ & $<25$ \\
\hline
\end{tabular}




\begin{tabular}{|c|c|c|c|c|}
\hline & 30 & $98.4 \pm 0.1$ & $92.0 \pm 0.7$ & $82.2 \pm 0.8$ \\
\hline $\mathbf{1 i}$ & 10 & $46.1 \pm 1.5$ & $25.9 \pm 1.5$ & $32.3 \pm 1.2$ \\
\hline & 30 & $52.4 \pm 2.0$ & $39.1 \pm 1.1$ & $38.6 \pm 1.9$ \\
\hline $\mathbf{2 i}$ & 10 & $40.3 \pm 1.7$ & $<25$ & $39.1 \pm 1.4$ \\
\hline $\mathbf{1 j}$ & 30 & $67.1 \pm 1.3$ & $62.5 \pm 2.1$ & $55.7 \pm 1.8$ \\
\hline & 10 & $34.8 \pm 1.5$ & $<25$ & $<25$ \\
\hline $\mathbf{2 j}$ & 30 & $38.3 \pm 1.6$ & $26.1 \pm 2.1$ & $27.6 \pm 1.0$ \\
\hline & 10 & $52.0 \pm 1.7$ & $23.8 \pm 1.6$ & $28.7 \pm 2.2$ \\
\hline Cisplatin & 30 & $71.4 \pm 0.4$ & $54.5 \pm 1.0$ & $70.8 \pm 1.4$ \\
\hline & 10 & $42.6 \pm 2.3$ & $53.0 \pm 2.3$ & $88.6 \pm 0.5$ \\
\hline & 30 & $99.9 \pm 0.3$ & $86.9 \pm 1.2$ & $90.2 \pm 1.8$ \\
\hline
\end{tabular}

\subsection{Antiproliferative properties of $15 \beta$-triazolyl-5 $\alpha$-androstanes}

\subsubsection{Determination of the antiproliferative effects of 15 $\beta$-triazolyl-5 $\alpha$-androstanes}

The activities were determined by using three malignant adherent cell lines (HeLa, A431 and MCF7) in the microplate-based MTT colorimetric assay in a two-step procedure (Table 3). Two final concentrations $(10$ and $30 \mu \mathrm{M})$ were first applied for all compounds. Although there is no generally accepted threshold for efficacy, a substance exhibiting less than $60 \%$ inhibition of cell growth at $30 \mu \mathrm{M}$ cannot be considered a promising lead compound. A set of dilutions were prepared $(1,3,10$ and $30 \mu \mathrm{M})$ and the most effective compounds were tested again and a sigmoidal dose-response curve was fitted to the measured points in order to determine the $\mathrm{IC}_{50}$ values.

Although not consequently, the 17-keto function seemed to be favored over the 17hydroxy group. The results of the MTT assays led to the selection of $\mathbf{3 a}-\mathbf{c}, \mathbf{4 a}$ and $\mathbf{4 b}$ for additional experiments in an attempt to elucidate the mechanism of their action. 
Table 3. Antiproliferative properties of $15 \beta$-triazolyl-5 $\alpha$-androstanes

\begin{tabular}{|c|c|c|c|}
\hline \multirow{2}{*}{3} & \multicolumn{3}{|c|}{ IC $_{\mathbf{5 0}}$ values $(\boldsymbol{\mu M}) *$} \\
\cline { 2 - 4 } & HeLa cells & MCF-7 cells & A431 cells \\
\hline 3b & 7.70 & 19.24 & 20.69 \\
\hline $\mathbf{3 c}$ & 9.40 & 10.28 & 22.43 \\
\hline $\mathbf{3 d}$ & 6.52 & $>30$ & $>30$ \\
\hline $\mathbf{4 a}$ & $>30$ & $>30$ & $>30$ \\
\hline $\mathbf{4 b}$ & 9.16 & 1.69 & 9.69 \\
\hline $\mathbf{4 c}$ & 10.27 & 2.68 & 10.66 \\
\hline $\mathbf{4 d}$ & 15.01 & 8.40 & $>30$ \\
\hline
\end{tabular}

* Mean value from two independent determinations with five parallel wells, standard deviation less than $15 \%$.

\subsubsection{Effects of 15 $\beta$-triazolyl-5 $\alpha$-androstanes on cell cycle}

Treatment of HeLa cells with 3 and $10 \mu \mathrm{M}$ of the selected agents for 24 or $48 \mathrm{~h}$ was followed by flow cytometric cell cycle analysis. The 24-h treatment with each of these compounds resulted in a concentration-dependent decrease in the number of cells in the G1 phase, and also in an accumulation of the G2/M population (Fig 4). Compound $\mathbf{3 c}$ did not exert any effect on the G2/M phase, but increased the proportion of cells in the synthetic (S) phase. Agents $\mathbf{3 a - c}$ and $\mathbf{4 a}$ also resulted in modest but statistically significant increases in the number of hypodiploid (subG1) cells, which are generally regarded as an apoptotic population. This apoptotic proportion became more pronounced after incubation for $48 \mathrm{~h}$. This finding suggests that, after treatment with these $5 \alpha$-androstane derivatives, the cells cannot complete the S-G2/M phases of the cell cycle and this blockade may initiate the apoptotic machinery. 

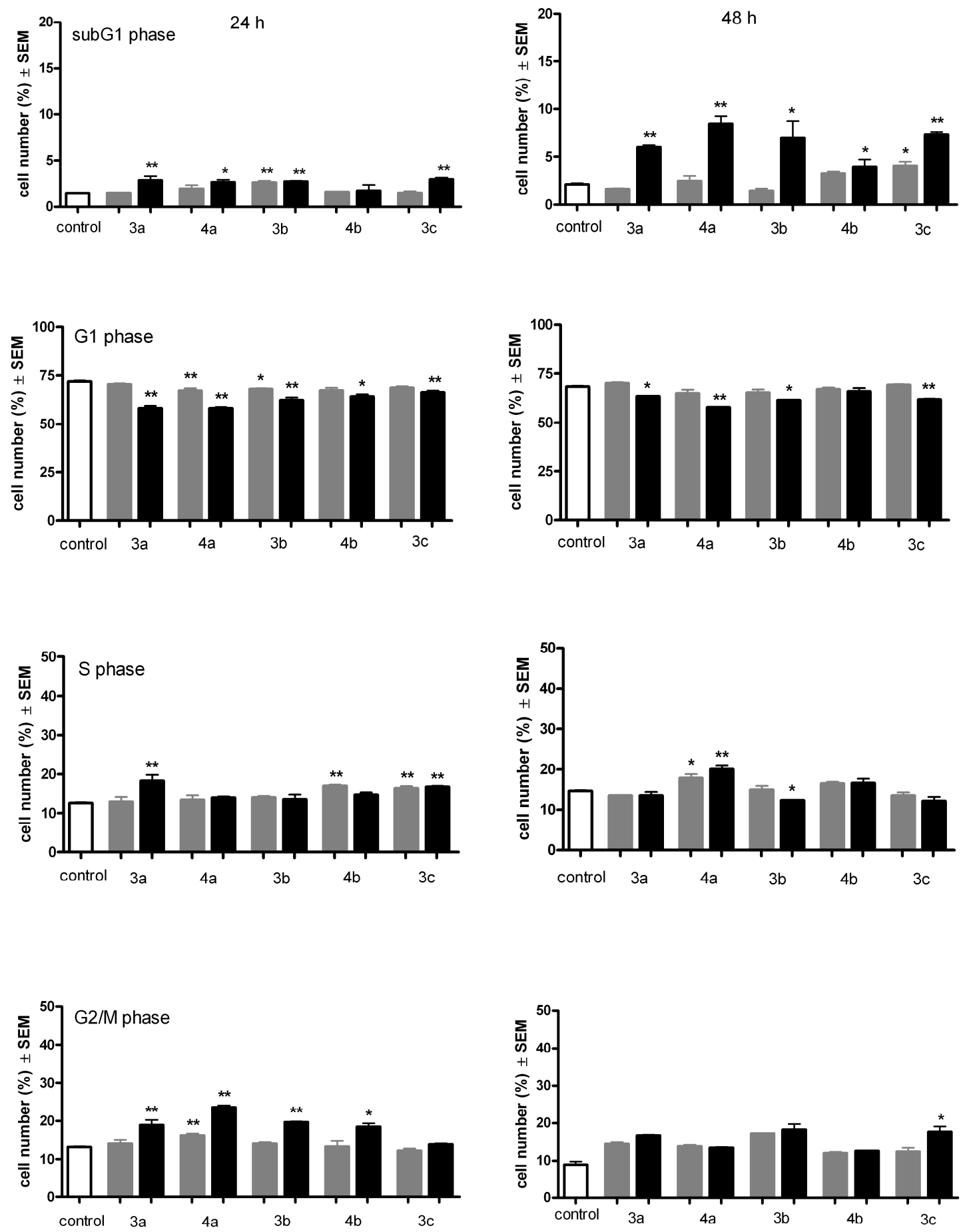

Figure 4. Effects of compounds 3a-c and 4a-b on HeLa cell cycle distribution after incubation for 24 and 48h. Columns represent mean values from three determinations. *and $* *$ indicate $p<0.05$ and $p<0.01$, respectively, as compared with the control cells. 


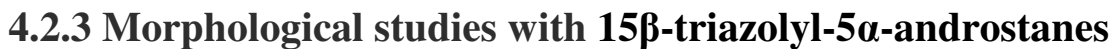

The programmed cell death-inducing capacities of the tested agents were confirmed by detection of the cell morphology and membrane integrity. Separate pictures were taken, illustrating Hoechst 33258 and propidium iodide (PI) fluorescence as morphological markers. After incubation for $24 \mathrm{~h}$, concentration-dependent increases in nuclear condensation and cell membrane permeability were generally detected, indicated by blue and red fluorescence, respectively (Figure 5).

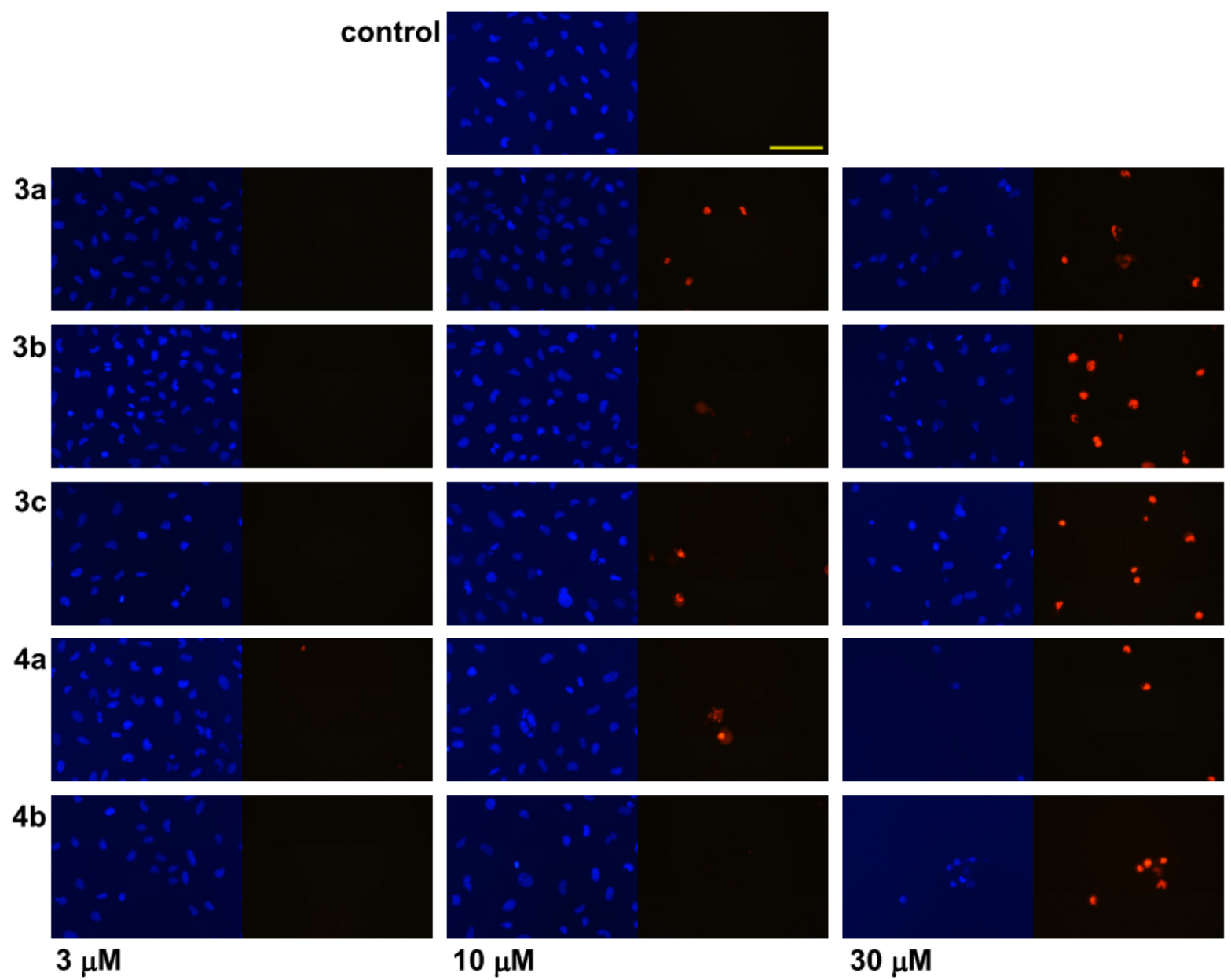

Figure 5. Fluorescence microscopy images of HOPI double staining. Two separate pictures from the same field have been recorded for the two markers. HeLa cells were treated with vehicle (control), or with 3a-c and $\mathbf{4 a}-\mathbf{b}$ at 3, 10 and $30 \mu \mathrm{M}$. The blue fluorescence indicates $\mathrm{HO}$, and the red coloration is a result of cellular PI accumulation. The bar in the HO control picture indicates $100 \mu \mathrm{m}$. 


\subsection{Antiproliferative properties of 16 $\alpha$-triazolylestrone derivatives}

\subsubsection{Determination of the antiproliferative effects of $16 \alpha$-triazolylestrone derivatives}

The antiproliferative properties of the prepared $16 \alpha$-triazolylestrone derivatives were determined on a panel of human cancerous cell lines (HeLa, A431 and MCF7) by means of the MTT assay in a two-step procedure. Two final concentrations (10 and $30 \mu \mathrm{M})$ were first applied for all compounds. For agents exhibiting a growth of inhibition at least $60 \%$ against any of the cell lines, further assays with lower concentrations were performed and the $\mathrm{IC}_{50}$ values were calculated. The cancer selectivities of these compounds were additionally determined by the same MTT assay against the noncancerous normal lung fibroblast cell line MRC5 (Table 4). Derivatives with an unsubstituted phenyl ring (5a and 6a) and those containing simple substituents $(\mathbf{5 b}-\mathbf{d}$ and $\mathbf{6 b}-\mathbf{d})$ or cycloalkyl groups $(\mathbf{5} \mathbf{j}-\mathbf{l}$ and $\mathbf{6} \mathbf{j}-\mathbf{l})$ also exerted moderate action. The introduction of a carbon chain (ethyl, propyl or isobutyl) on the aromatic moiety, however, resulted in increased activities, and these molecular elements combined with $17 \beta$-hydroxy groups generated the most potent members of the current set $(\mathbf{6 f}-$ h). The $m$-aminophenyl-substituted heteroaromatic ring resulted in another effective compound, but in this case the $17 \alpha$-hydroxy epimer (5i) proved to be more potent. On the basis of their antiproliferative effects, compounds $5 \mathbf{i}$ and $\mathbf{6 f}-\mathbf{h}$ were selected for further experiments, including characterization of the cancer selectivity. All four steroids exerted limited action on the proliferation of noncancerous fibroblast MRC5. In the cases of $\mathbf{5 i}$ and 6h, $50 \%$ inhibition was not elicited up to $30 \mu \mathrm{M}$. 
Table 4. Antiproliferative properties of the synthetized compounds

\begin{tabular}{|c|c|c|c|c|c|}
\hline \multirow[t]{2}{*}{ Compound } & \multirow{2}{*}{$\begin{array}{l}\text { Conc. } \\
(\mu \mathrm{M})\end{array}$} & \multicolumn{4}{|c|}{$\begin{array}{c}\text { Inhibition } \% \pm \text { SEM } \\
{\text { [Calculated } \mathrm{IC}_{50} \text { value }^{\mathrm{a}}}\end{array}$} \\
\hline & & HeLa & MCF7 & A431 & MRC5 \\
\hline \multirow[t]{3}{*}{$5 \mathbf{a}$} & 10 & $37.44 \pm 2.44$ & - & $34.92 \pm 0.58$ & n.d. \\
\hline & 30 & $68.28 \pm 0.54$ & $49.93 \pm 0.63$ & $47.92+1.24$ & \\
\hline & & {$[10.21 \mu \mathrm{M}]$} & {$[>30 \mu \mathrm{M}]$} & {$[>30 \mu \mathrm{M}]$} & \\
\hline \multirow[t]{2}{*}{$5 b$} & 10 & - & - & - & n.d. \\
\hline & 30 & - & - & - & \\
\hline \multirow[t]{2}{*}{$5 c$} & 10 & - & - & - & n.d. \\
\hline & 30 & - & - & - & \\
\hline \multirow[t]{2}{*}{$5 d$} & 10 & - & - & - & n.d. \\
\hline & 30 & $45.45 \pm 0.84$ & $28.79 \pm 1.51$ & $26.13 \pm 2.30$ & \\
\hline \multirow[t]{3}{*}{$5 e$} & 10 & $51.34 \pm 0.62$ & $34.13 \pm 2.14$ & $41.87 \pm 1.92$ & n.d. \\
\hline & 30 & $71.39 \pm 1.17$ & $64.39 \pm 1.15$ & $55.47 \pm 0.79$ & \\
\hline & & {$[14.80 \mu \mathrm{M}]$} & {$[17.78 \mu \mathrm{M}]$} & {$[22.76 \mu \mathrm{M}]$} & \\
\hline \multirow[t]{3}{*}{$5 f$} & 10 & $47.07 \pm 1.06$ & $61.87 \pm 2.59$ & - & n.d. \\
\hline & 30 & $97.30 \pm 0.49$ & $96.36 \pm 0.44$ & $29.21 \pm 2.76$ & \\
\hline & & {$[10.68 \mu \mathrm{M}]$} & {$[8.07 \mu \mathrm{M}]$} & {$[>30 \mu \mathrm{M}]$} & \\
\hline \multirow[t]{2}{*}{$5 \mathrm{~g}$} & 10 & - & - & - & n.d. \\
\hline & 30 & $51.62 \pm 2.04$ & - & - & \\
\hline \multirow[t]{3}{*}{$5 \mathrm{~h}$} & 10 & - & - & - & n.d. \\
\hline & 30 & $92.85 \pm 0.41$ & $66.63 \pm 1.19$ & $42.59 \pm 1.14$ & \\
\hline & & {$[11.68 \mu \mathrm{M}]$} & {$[11.58 \mu \mathrm{M}]$} & {$[>30 \mu \mathrm{M}]$} & \\
\hline \multirow[t]{3}{*}{$5 i$} & 10 & $47.24 \pm 2.13$ & - & $26.98 \pm 0.87$ & - \\
\hline & 30 & $98.38 \pm 0.15$ & $82.48 \pm 0.85$ & $94.70 \pm 0.46$ & $25.74 \pm 2.94$ \\
\hline & & {$[13.85 \mu \mathrm{M}]$} & {$[14.88 \mu \mathrm{M}]$} & {$[11.75 \mu \mathrm{M}]$} & {$[>30 \mu \mathrm{M}]$} \\
\hline \multirow[t]{2}{*}{$5 \mathbf{j}$} & 10 & - & $30.96 \pm 1.71$ & $35.79 \pm 1.53$ & n.d. \\
\hline & 30 & $51.49 \pm 1.92$ & $43.48 \pm 1.30$ & $49.96 \pm 1.43$ & \\
\hline \multirow[t]{2}{*}{$5 \mathbf{k}$} & 10 & $25.33 \pm 2.54$ & - & - & n.d. \\
\hline & 30 & $38.09 \pm 2.03$ & $47.94 \pm 1.15$ & - & \\
\hline \multirow[t]{2}{*}{51} & 10 & - & - & - & n.d. \\
\hline & 30 & $34.44 \pm 2.14)$ & $33.29 \pm 2.51$ & $26.92 \pm 1.75$ & \\
\hline \multirow[t]{2}{*}{$6 \mathbf{a}$} & 10 & - & - & - & n.d. \\
\hline & 30 & $34.63 \pm 2.14$ & $39.95 \pm 1.96$ & $52.94 \pm 0.70$ & \\
\hline
\end{tabular}




\begin{tabular}{|c|c|c|c|c|c|}
\hline \multirow[t]{2}{*}{$6 \mathbf{b}$} & 10 & $40.54 \pm 0.74$ & - & $44.29 \pm 0.73$ & n.d. \\
\hline & 30 & $50.06 \pm 1.13$ & - & $44.71 \pm 1.63$ & \\
\hline \multirow[t]{2}{*}{$6 c$} & 10 & - & - & - & n.d. \\
\hline & 30 & $36.57 \pm 1.08$ & $44.20 \pm 1.54$ & $58.09 \pm 0.21$ & \\
\hline \multirow[t]{2}{*}{ 6d } & 10 & $37.41 \pm 1.16$ & $26.05 \pm 2.73$ & - & n.d. \\
\hline & 30 & $46.76 \pm 2.95$ & $37.10 \pm 2.35$ & $49.14 \pm 2.13$ & \\
\hline \multirow[t]{2}{*}{$6 e$} & 10 & $31.65 \pm 2.53$ & - & - & n.d. \\
\hline & 30 & $40.81 \pm 2.35$ & - & - & \\
\hline \multirow[t]{3}{*}{$6 f$} & 10 & $90.47 \pm 0.53$ & $73.15 \pm 1.39$ & $72.94 \pm 0.87$ & $32.75 \pm 2.49$ \\
\hline & 30 & $95.17 \pm 0.27$ & $78.94 \pm 0.55$ & $70.98 \pm 0.86$ & $68.32 \pm 0.76$ \\
\hline & & {$[5.08 \mu \mathrm{M}]$} & {$[7.88 \mu \mathrm{M}]$} & {$[6.77 \mu \mathrm{M}]$} & {$[17.64 \mu \mathrm{M}]$} \\
\hline \multirow[t]{3}{*}{$6 \mathbf{g}$} & 10 & $85.62 \pm 0.75$ & $44.84 \pm 2.19$ & $47.32 \pm 1.02$ & $33.74 \pm 1.74$ \\
\hline & 30 & $95.55 \pm 0.62$ & $60.60 \pm 1.97$ & $73.60 \pm 0.46$ & $68.61 \pm 1.22$ \\
\hline & & {$[8.69 \mu \mathrm{M}]$} & {$[10.78 \mu \mathrm{M}]$} & {$[10.68 \mu \mathrm{M}]$} & {$[17.07 \mu \mathrm{M}]$} \\
\hline \multirow[t]{3}{*}{$6 h$} & 10 & $75.26 \pm 1.57$ & $32.80 \pm 2.59$ & $43.15 \pm 1.87$ & $21.01 \pm 1.58$ \\
\hline & 30 & $86.44 \pm 0.57$ & $36.30 \pm 1.26$ & $51.76 \pm 1.52$ & $20.44 \pm 1.29$ \\
\hline & & {$[12.11 \mu \mathrm{M}]$} & {$[>30 \mu \mathrm{M}]$} & {$[>30 \mu \mathrm{M}]$} & {$[>30 \mu \mathrm{M}]$} \\
\hline \multirow[t]{2}{*}{$6 \mathbf{i}$} & 10 & - & - & - & n.d. \\
\hline & 30 & $24.55 \pm 2.69$ & $64.62 \pm 1.71$ & - & \\
\hline \multirow[t]{2}{*}{$\mathbf{6 j}$} & 10 & - & - & - & n.d. \\
\hline & 30 & $40.47 \pm 2.39$ & - & - & \\
\hline \multirow[t]{2}{*}{$6 \mathbf{k}$} & 10 & $26.28 \pm 1.23$ & - & - & n.d. \\
\hline & 30 & $34.55 \pm 1.61$ & - & - & \\
\hline \multirow[t]{2}{*}{61} & 10 & - & - & - & n.d. \\
\hline & 30 & $26.54 \pm 2.16$ & - & - & \\
\hline \multirow[t]{3}{*}{ Cisplatin } & 10 & $42.61 \pm 2.33$ & $53.03 \pm 2.29$ & $88.54 \pm 0.50$ & $72.30 \pm 2.30$ \\
\hline & 30 & $99.93 \pm 0.26$ & $86.90 \pm 1.24$ & $90.18 \pm 1.78$ & $70.65+1.34$ \\
\hline & & {$[12.43 \mu \mathrm{M}]$} & {$[9.63 \mu \mathrm{M}]$} & {$[2.84 \mu \mathrm{M}]$} & {$[4.51 \mu \mathrm{M}]$} \\
\hline
\end{tabular}

${ }^{a}$ Mean value from two independent determinations with five parallel wells, standard deviation less than $15 \%$. ${ }^{b}$ Inhibition values $<25 \%$ are not presented for clarity. ${ }^{\mathrm{c}}$ n.d.: not determined 


\subsubsection{Effects of 16 $\alpha$-triazolylestrone derivatives on cell cycle}

HeLa cells were treated with the tested compounds at 3 and $10 \mu \mathrm{M}$ for 24 and $48 \mathrm{~h}$, and the phase distribution of the treated cells was determined (Fig. 6). Treatment with the selected estrane analogs resulted in a concentration-dependent increase of subG1 phase cells, which was more pronounced after incubation for $48 \mathrm{~h}$. At the same time, the G1 populations decreased substantially, while the synthetic and G2/M phases exhibited modest, but significant increases. Though compound $6 \mathbf{f}$ proved to be the most potent inducer of the hypodiploid cell population, no substantial differences were evidenced in the cell cycle distributions of the treated cells. 

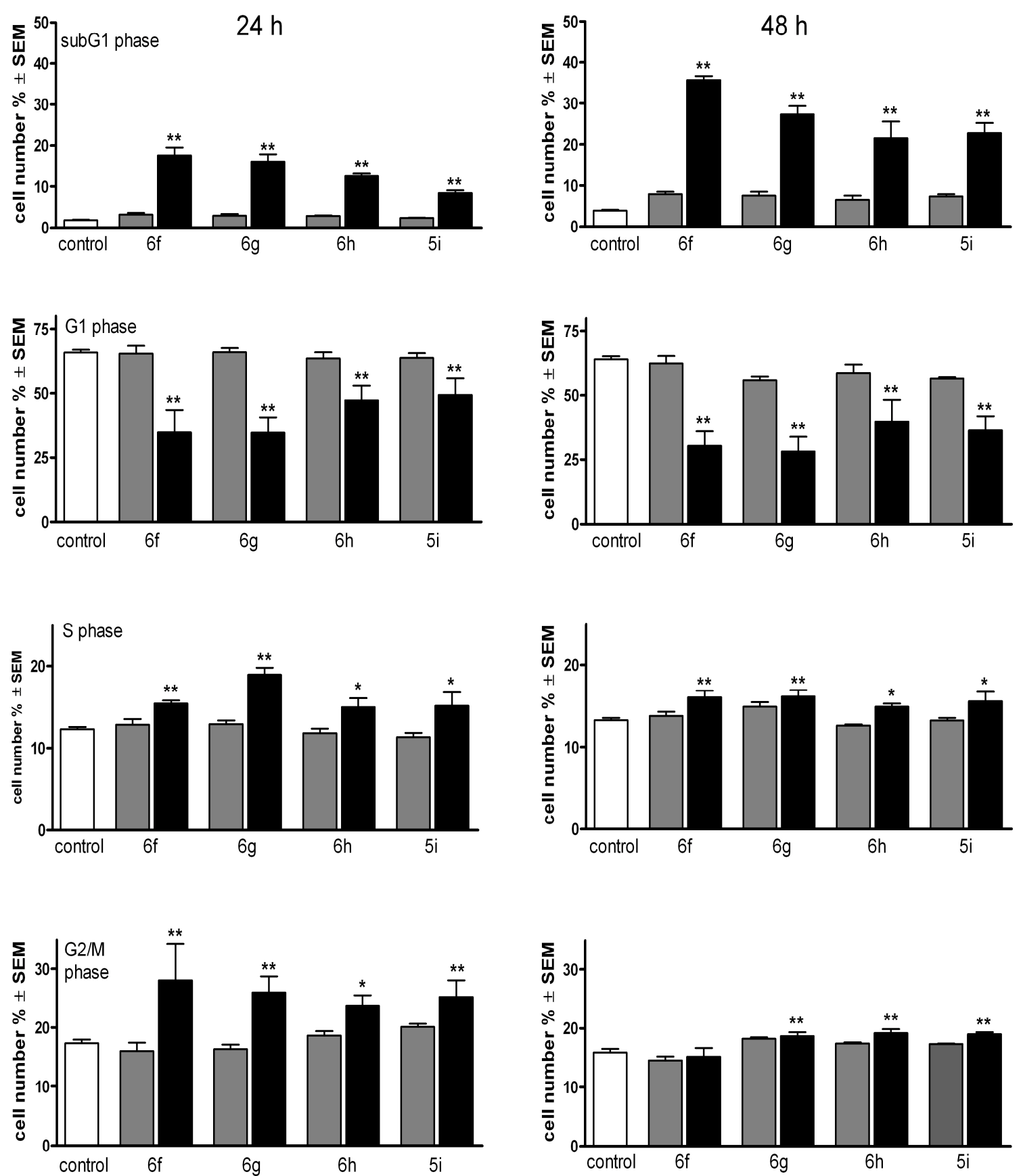

Figure 6. Effects of compounds $6 \mathbf{6}, \mathbf{6 g}, \mathbf{6 h}$ and $5 \mathbf{i}$ on the HeLa cell cycle distribution after incubation for 24 (left panels) and $48 \mathrm{~h}$ (right panels). Grey and black columns indicate 3 and $10 \mu \mathrm{M}$, respectively. $*$ and $* *$ denote $\mathrm{p}<0.05$ and $\mathrm{p}<0.01$, respectively, as compared with the control cells. 


\subsubsection{Morphological studies with 16 $\alpha$-triazolylestrone derivatives}

HeLa cells were treated with the steroids in concentrations of 3, 10 and $30 \mu \mathrm{M}$ and then incubated for $24 \mathrm{~h}$ and stained with the fluorescent DNA markers HO and PI in order to evaluate the morphological markers of the effects induced by the tested compounds. Two separate pictures from the same field were taken for the two fluorescent dyes. Morphological changes such as nuclear condensation, the appearance of apoptotic bodies and increase of the cell membrane permeability were recognized in a concentration-dependent manner as evidence of apoptosis and necrosis (Fig. 7). All four selected steroids (5i, 6f, $6 \mathbf{g}$ and $\mathbf{6 h}$ ) in a concentration of $3 \mu \mathrm{M}$ induced early apoptosis, as confirmed by nuclear condensation without increased membrane permeability. The gradual impairment of the membrane function was detected by more frequent PI staining on increase of the applied concentration, which may be evidence of late apoptosis or necrosis. Treatment with $30 \mu \mathrm{M}$ of these compounds resulted in disturbed membrane permeability, without the corresponding nuclear condensation indicating the necrosis-inducing capacity of the agents.

Since two of the selected steroids (6f and $\mathbf{6 g}$ ) elicited substantial antiproliferative effects on MRC5 cells too, the staining was extended to these noncancerous cells with identical concentrations and incubation period (Fig. 8). Sparse nuclear condensation was evidenced in fibroblast cells treated with higher concentrations $(10$ or $30 \mu \mathrm{M})$, without marked PI staining. 


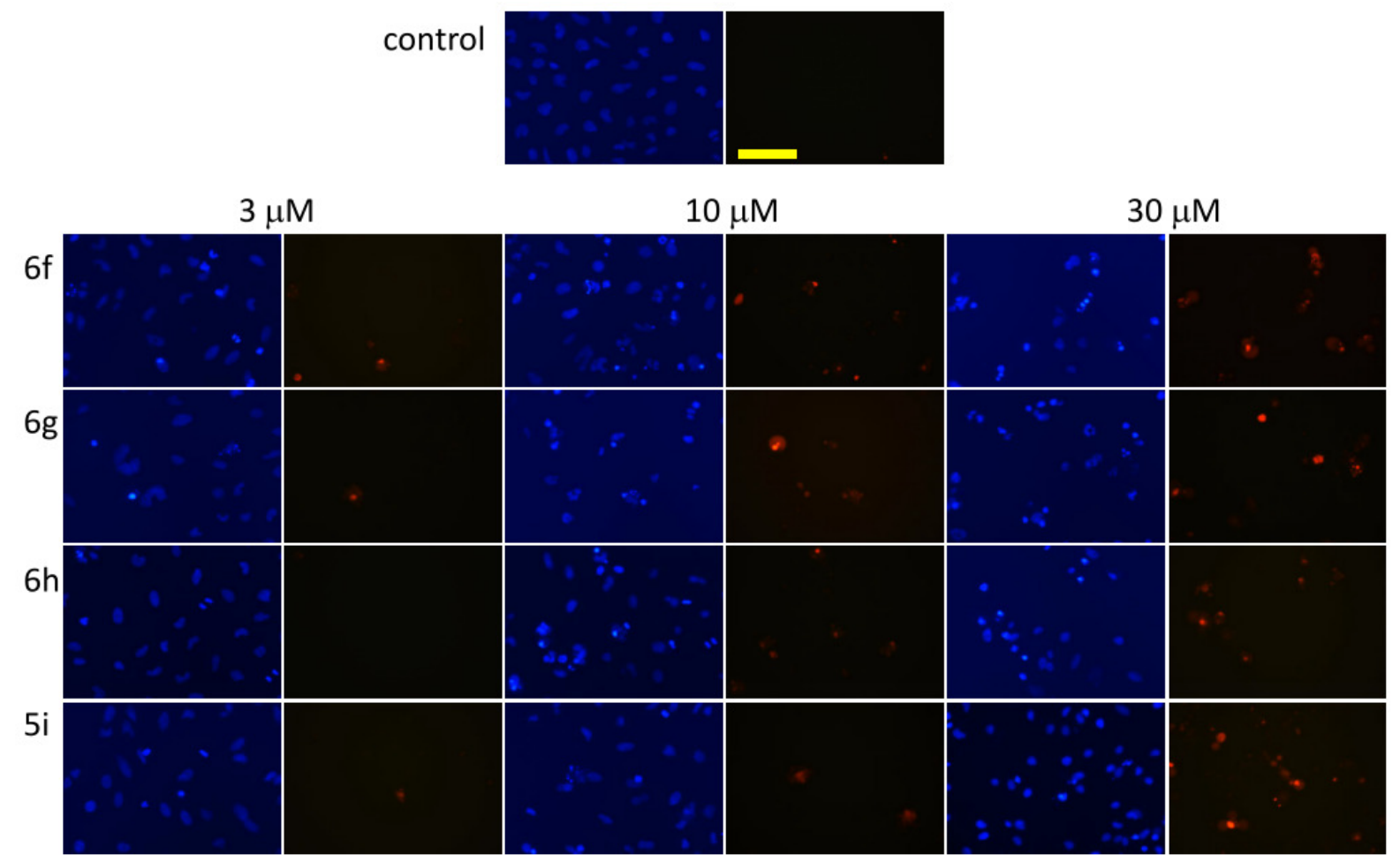

Figure 7. Fluorescent microscopy images of HO-PI double staining. Two separate pictures from the same field were taken for the two markers. HeLa cells were treated with vehicle (control), or treated with $\mathbf{6 f}, \mathbf{6 g}, \mathbf{6 h}$ and $5 \mathbf{i}$ at the indicated concentrations. The blue fluorescence (left panels) indicates $\mathrm{HO}$ and the red fluorescence (right panels) is a consequence of PI accumulation. The bar in the PI control picture indicates $100 \mu \mathrm{m}$. 


\section{control}

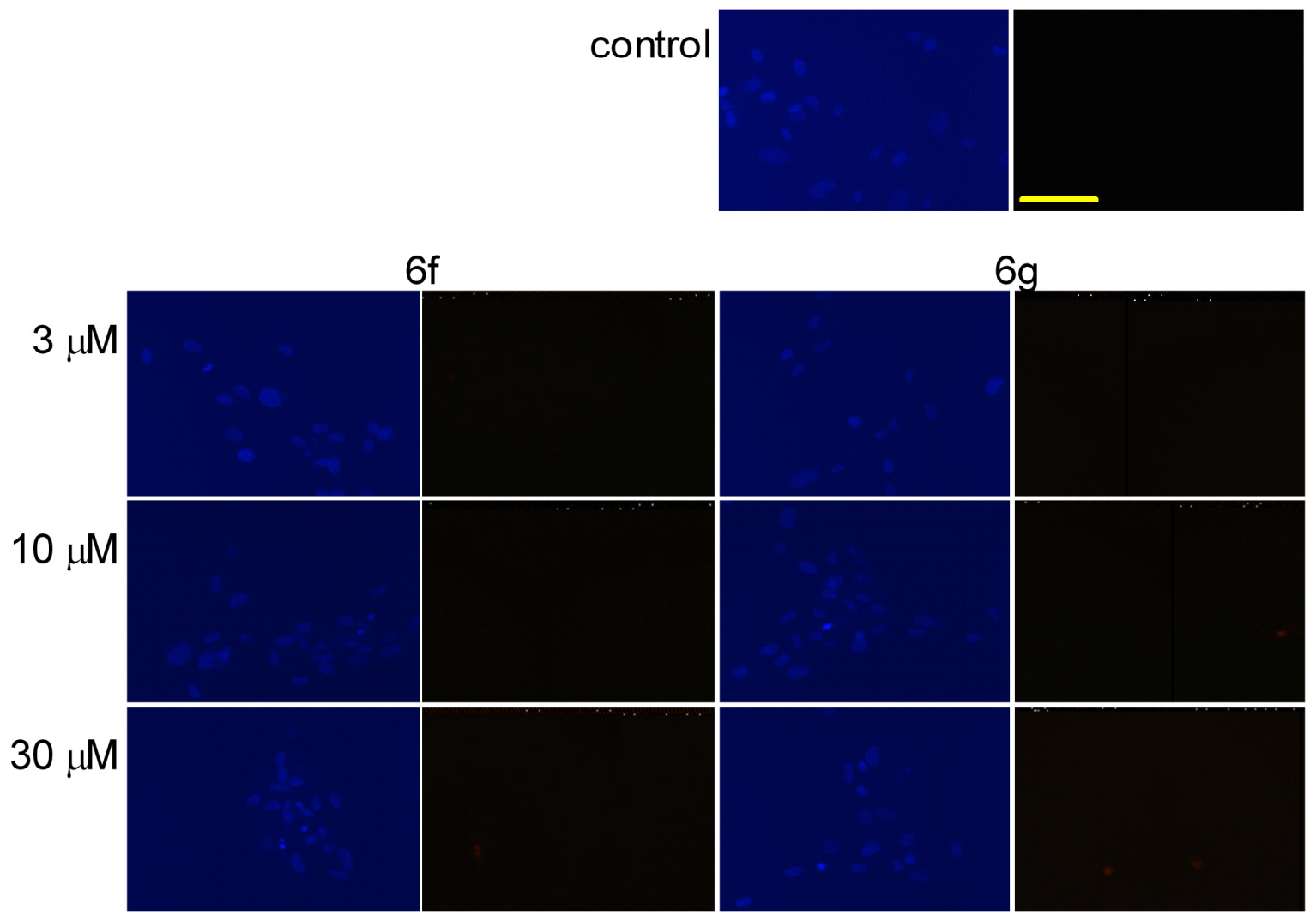

Figure 8. Fluorescent microscopy images of Hoechst 33258-PI double staining. Two separate pictures from the same field were taken for the two markers. MRC5 cells were treated with vehicle (control), or with $\mathbf{6 f}$ and $\mathbf{6 g}$ at the indicated concentrations. The blue fluorescence (left panels) indicates Hoechst 33258, and the red fluorescence (right panels) is a consequence of PI accumulation. The bar in the PI control picture indicates $100 \mu \mathrm{m}$. 


\subsubsection{Caspase-3, caspase-8 and caspase-9 assays}

Based on the results of cell cycle analysis and HO-PI double staining, the effects of two selected agents (6f and $\mathbf{6 g}$ ) on the activities of the apoptotic key enzymes caspase-3, caspase- 8 and caspase- 9 were determined. Both steroid analogs activated the executive caspase-3 in a concentration-dependent way during a 24-h incubation (Fig. 9). Agent $\mathbf{6 g}$ exerted more pronounced action in this respect. The activity of the initiator caspase- 9 was also significantly increased by both agents, though the extents were less pronounced. $24 \mathrm{~h}$ of exposure to agent $\mathbf{6} \mathbf{f}$ resulted in similarly elevated enzyme activities in the concentration range 3-30 $\mu \mathrm{M}$, while agent $\mathbf{6 g}$ caused concentration-dependent caspase-9 activation. On the other hand, none of the tested agents elicited significant activation of caspase- 8 .

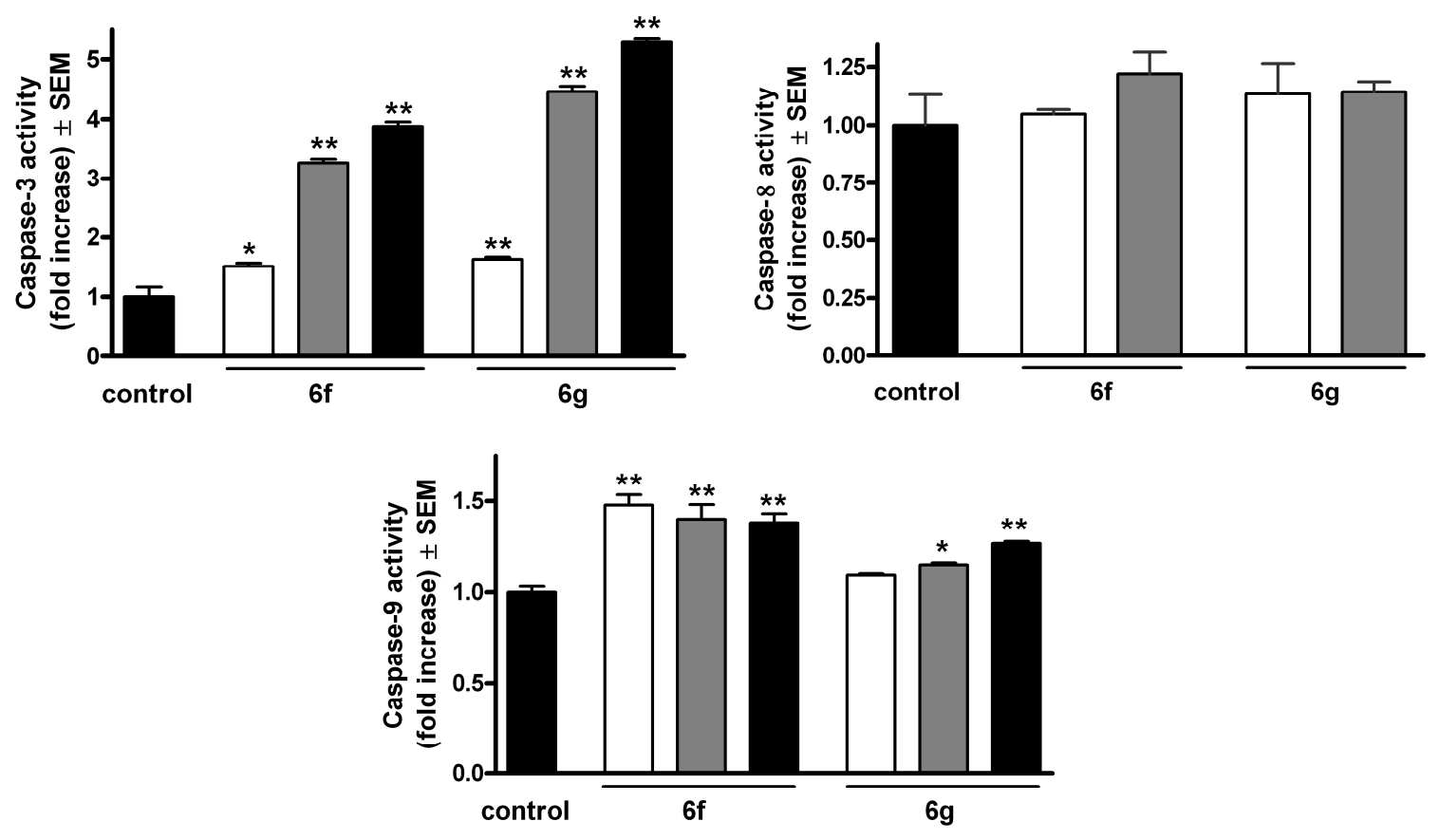

Figure 9. Induction of caspase-3, caspase- 8 and caspase-9 activities after incubation with compounds $6 \mathbf{f}$ and $\mathbf{6 g}$ for $24 \mathrm{~h}$. White, gray and black columns denote 3,10 and $30 \mu \mathrm{M}$ of the given agent. $*$ and $* *$ denote $\mathrm{p}<0.05$ and $\mathrm{p}<0.01$, respectively, as compared with the control condition. 


\subsubsection{RT-PCR studies}

The expressions of the cell cycle regulator factors of the G2-M transition (CDK1, cyclin B1, cyclin B2 and $\operatorname{cdc} 25 \mathrm{~B}$ ) and factors that play key roles in the mitochondrial pathway of apoptosis (Bax and Bcl-2) were determined at the mRNA level by means of RTPCR. From the results of cell cycle analysis and caspase- 3 and caspase- 9 assays, the effects of the two most effective compounds at 3 and $10 \mu \mathrm{M}$ on these mRNA sequences were determined following a 24-h incubation. Two well-characterized proteins responsible for the regulation of outer mitochondrial membrane permeability, Bax and $\mathrm{Bcl}-2$, did not exhibit substantial differences (data not presented). However, under otherwise the same conditions, the ratio $\mathrm{Bax} / \mathrm{Bcl}-2$ was significantly higher at the higher concentration for both compounds (Fig. 10). This indicates activation of the mitochondrial pathway of apoptosis.

All four selected factors responsible for the G2-M transition were decreased after treatment with the higher concentration $(10 \mu \mathrm{M})$. Moreover, the expression of cyclin B1 at the mRNA level was significantly reduced even after treatment with $3 \mu \mathrm{M}$ of $\mathbf{6 g}$ (Fig. 11).

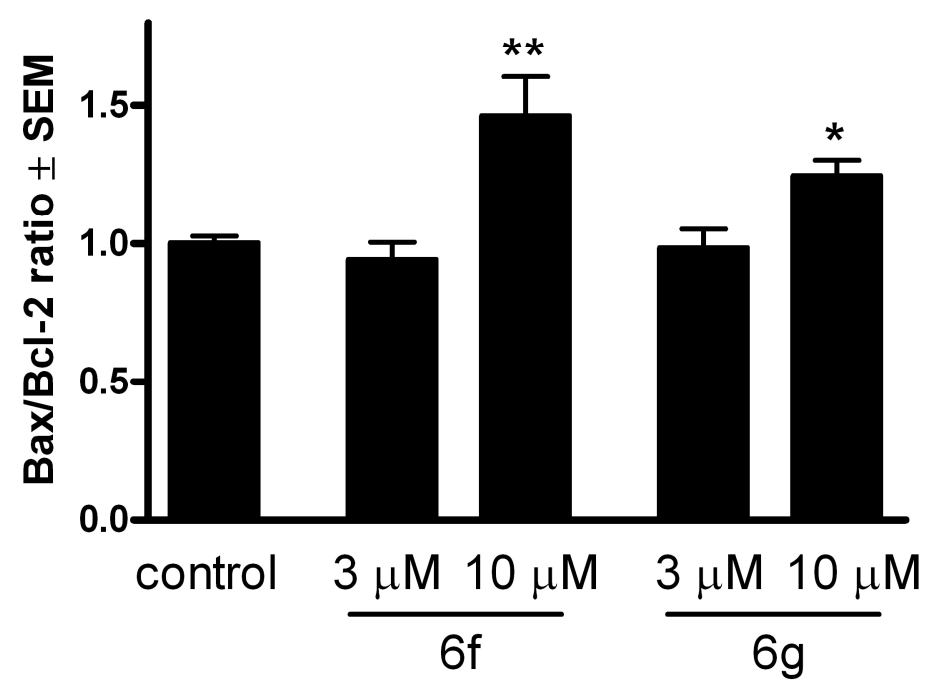

Figure 10. Effects of compounds $6 \mathbf{f}$ and $\mathbf{6 g}$ on the Bax/Bcl-2 ratio after incubation of HeLa cells for 24 h. $*$ and $* *$ denote $\mathrm{p}<0.05$ and $\mathrm{p}<0.01$, respectively, as compared with the control condition. 


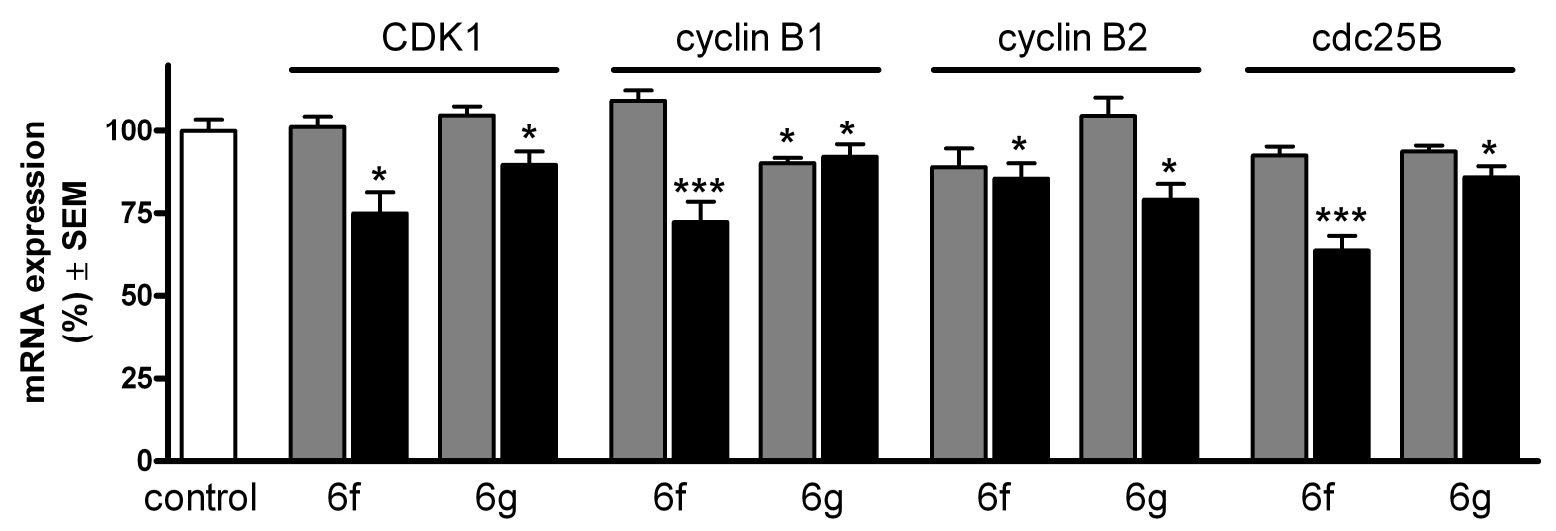

Figure 11. Expression of CDK1, cyclin B1, cyclin B2 and cdc25B at the mRNA level after incubation with 3 (grey columns) or 10 (black columns) $\mu \mathrm{M}$ of compounds $6 \mathbf{f}$ or $\mathbf{6 g}$. *, ** and *** denote $\mathrm{p}<0.05, \mathrm{p}<0.01$ and $\mathrm{p}<0.001$, respectively, as compared with the control condition. 


\subsubsection{Western blotting studies}

In response to a $48-\mathrm{h}$ exposure to $10 \mu \mathrm{M}$ 6f or $\mathbf{6 g}$, the protein expression of phosphorylated stathmin, a microtubule destabilizing protein, was significantly increased severalfold as compared to untreated control cells (Fig. 12). On the other hand, the total amount of stathmin did not display any significant alteration indicating a change in the phosphorylation state of the protein.
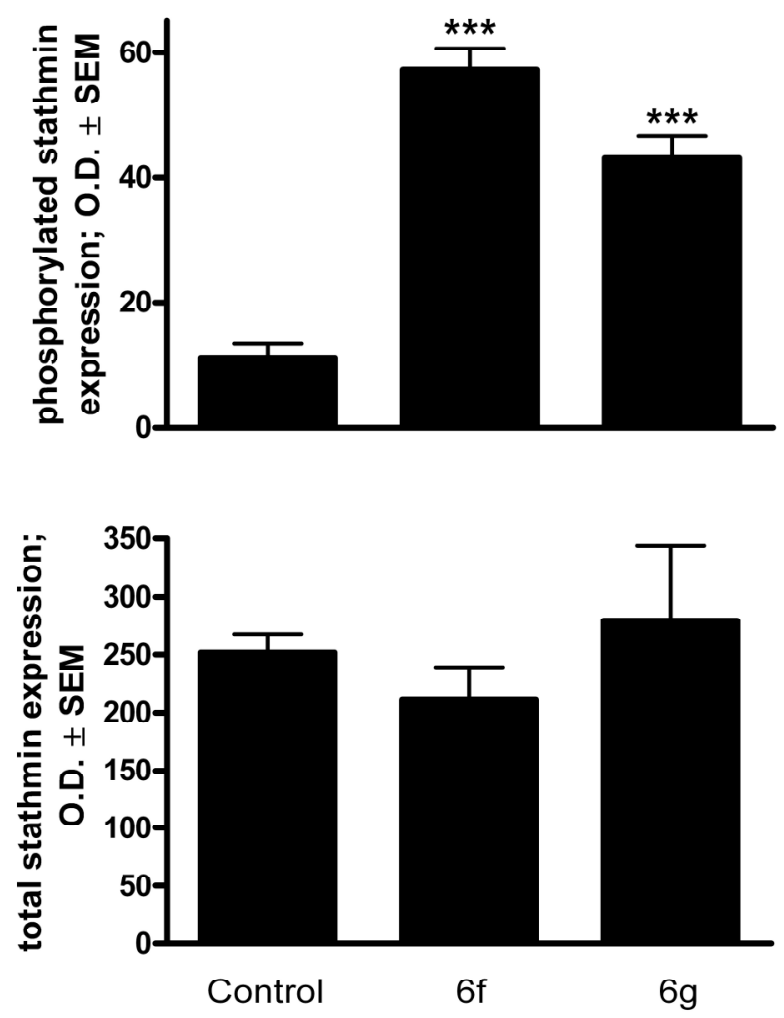

Figure 12. Effects of $\mathbf{6 f}$ and $\mathbf{6 g}(10 \mu \mathrm{M})$ on the expression of phosphorylated (upper panel) and total (lower panel) stathmin protein in HeLa cells after incubation for $48 \mathrm{~h}$, determined by Western blot analysis. Results are mean values \pm SEM of the data on two separate measurements, $\mathrm{n}=6 . * * *$ indicates $\mathrm{p}<0.001$ as compared with the untreated control cells. 


\section{DISCUSSION}

Compounds with a steroidal skeleton may exert an extremely broad variety of pharmacological activities in spite of the conserved chemical structure. The steroid backbone can therefore be utilized for the design and synthesis of a wide range of drug candidates.

A convincing amount of evidence has accumulated concerning the anticancer efficacy of natural steroids isolated from plants and their synthetic analogs. The cancer-preventing properties of cardiotonics (e.g. digoxin and digitoxin) traditionally used in the treatment of congestive heart failure have been recognized in retrospective epidemiological analyses (Stenkvist, 1999). These findings suggested the extension of the field of indication of the currently utilized digitaloids, and intensive research has therefore been initiated to develop a digitalis-based, novel class of antitumor agents (Mijatovic et al., 2007).

The antiproliferative action of a set of solanidine analogs against HeLa cells was reported recently. Some of these steroids substantially inhibited the outflow of rhodamine-123 from murine lymphoma cells, mediated by the ABCB1 transporter (Zupkó et al., 2014).

Many steroidal alkaloids, including $\alpha$-tomatidine and solanidine, inhibited the growth of human cancer cell lines at reasonable concentrations, whereas this action was less pronounced for their aglycones tomatidine and solanidine, respectively, indicating that the attractive properties of the steroid scaffold can be improved by an appropriately selected smaller substituent (Lee et al., 2004). This concept was utilized in our current work, in which a substituted triazolyl ring was introduced onto the estrane core.

The triazole ring is a five-membered heterocycle containing three nitrogen atoms. It has aromaticity and an electron rich system and because of this it enables triazole derivatives to bind with a variety of enzymes and receptors. Triazole compounds such as anastrozole, letrozole are very important antihormonal drugs and a large number of triazole compounds have been exploited as anticancer drugs or candidates in recent years. The structural modification of known anticancer drugs leads to the development of new structural triazole compounds as anticancer agents. N-Aryltriazole by the introduction of a 1,2,3-triazole ring into doxifluridine, used in the clinical practice, exhibited the higher anticancer activity against three human cell lines (Vero, MT-4, and HeLa) and it has no cytotoxic activity even at a high concentration of $300 \mu \mathrm{mol} / \mathrm{L}$. Natural artemisinin used in antimalarial therapy showed no anticancer activity. Artemisinin inhibits cell proliferation of different malignant cells in the case of the introduction of a triazole ring at the position of carbonyl moiety (Zhou and Wang, 2012). Based on these data, the triazole ring can be regarded as a pharmacophoric moiety. 
Estrogens are generally regarded as cellular proliferation-potentiating factors, and this is especially true for some malignancies of gynecological origin. Of the many estrane-related antiproliferative compounds recently described, the most widely investigated (and even subjected to clinical trial) is an endogenous metabolite of estrone, 2-methoxyestradiol, which exerts its anticancer effect by eliciting an imbalance of the microtubule dynamics and the direct inhibition of neoangiogenesis (Kambhampati et al., 2012, Peyrat et al., 2012).

A set of estrone-16-oxime ethers was recently synthetized and tested for anticancer properties. The most potent analogs inhibited DNA synthesis in Hela cells, changed the expression of endogenous factors regulating the G1-S transition (retinoblastoma protein, CDK4 and p16) and induced apoptosis (Berényi et al., 2013).

Since most, if not all, of the currently used anticancer agents possess the ability to initiate programmed cell death by modifying the balance between apoptotic and antiapoptotic signaling, the demonstration of apoptosis induction is a critical step in the development of an anticancer drug candidate (Tolomeo and Simoni, 2002). Treatment with each of the four selected molecules $(\mathbf{5 i}, \mathbf{6 f}, \mathbf{6 g}$ and $\mathbf{6 h})$ for $24 \mathrm{~h}$, even at the lowest concentration $(3 \mu \mathrm{M})$, resulted in nuclear condensation with minimal or no disruption in membrane permeability, which is a morphological marker of apoptosis. Flow cytometry was utilized for a quantitative description of the cell cycle distribution of the treated cells. The most effective agents increased the hypodiploid (subG1) population in a concentration- and time-dependent manner. The reduced DNA stainability is considered to be a consequence of the progressive loss of DNA due to activation of endonuclease and the elimination fragments as part of the selfdecomposition during apoptosis (Vermes et al., 2000).

Since the present compounds contain an estrane skeleton, interaction with estrogenic receptors seems a possible mechanism of action. Additionally, their potential estrogenic activity is a reasonable question. On the basis of a well-established structure-activity relationship, any action mediated through estrogenic receptors can be excluded (Anstead et al., 1997). The 3-OH group of estradiol is needed as an H-bond donor in its interaction with its receptors, and the 3-methyl ether of estradiol exhibits less than $1 \%$ relative binding affinity. A bulky 16- $\alpha$ substituent is another structural feature which abolishes the estrogenic activities of estranes.

Caspases are cysteinyl aspartate proteinases present in almost all intact cells as inactive precursors which become activated by proteolytic cleavage upon receiving apoptotic stimuli. In mammals, 18 caspases have been identified and are classified into initiator and executioner caspases according to their role in the apoptotic machinery (Kumar, 2007). In 
spite of the fact that both caspase- 3 and caspase- 9 have been implicated in non-apoptotic functions, the activation of these enzymes in cancer cell cultures can still be regarded as an indication of apoptotic execution and initiation of its intrinsic pathway, respectively (Connolly et al., 2014). From the aspect of the caspase activation pattern of the two selected compounds, it may be pointed out to that they induce apoptosis via the intrinsic pathway. The activation of caspase-9 seems less pronounced, which is not unusual in view of the fact that this enzyme is the first element in a cascade, while caspase- 3 is a terminal element and therefore a product of amplification.

Since the mitochondria maintain the capacity to initiate the controlled cellular decomposition upon receiving appropriate signals, they serve as a central hub in the regulation of the apoptosis-survival balance. The mitochondrial pathway of apoptosis is induced by the permeabilization of its outer membrane, resulting in cytochrome c release and the subsequent formation of the apoptosome, a multiprotein complex acting as a scaffold for successive events of apoptosis. The permeabilization of the outer mitochondrial membrane is therefore a crucial event and strictly regulated by the members of the Bcl-2 protein family. Although an antiapoptotic subfamily, including Bcl-2, Bcl-xl and Mcl-1, maintains a balance with some proapoptotic proteins (Bax and Bak), Bcl-2 and Bax are frequently investigated representative members of the two subgroups (Brinkmann and Kashkar, 2014). Their relation is generally regarded as a marker of the apoptotic-survival balance (Xu et al., 2014). The higher concentrations of both selected compounds (6f and $\mathbf{6 g}$ ) resulted in a significant increase in the ratio $\mathrm{Bax} / \mathrm{Bcl}-2$, reinforcing the mitochondrial origin of the detected apoptosis.

Cell division is a highly complex procedure involving an incompletely described array of regulatory steps, most of which are controlled by reversible protein phosphorylation. Specifically, the activity of the cyclin B-CDK1 complex is pivotal in regulating the G2-M phase transition, and especially in the initiation of chromosome condensation (Lindqvist et al., 2005). CDK1 is maintained inactive during most of the cell cycle through phosphorylation by Wee1 and Myt1 kinases. When CDK1 activity becomes required for the progression into the $\mathrm{M}$ phase, cdc25 phosphatase dephosphorylates the CDK1-containing complex. In mammals, three isoforms of cdc25 have been identified: cdc25A, cdc25B and cdc25C. The overexpression of $\mathrm{CDC} 25 \mathrm{~A}$ and $\mathrm{CDC} 25 \mathrm{~B}$ is reported to be involved in carcinogenesis and is associated with poor prognosis (Boutros et al., 2007). The functional differences between these isoforms have not been fully elucidated, but the normal development of CDC25B and CDC25C double knockout mice indicates that CDC25A is capable of performing all the essential operations (Ferguson et al., 2005). CDC25B was proposed to be responsible for the 
initial activation of cyclin B-CDK1 complex during G2-M phase transition in HeLa cells (Gabrielli et al., 1996). This led us to select the most terminal executive regulators of cell cycle transition for determination of their expression at the mRNA level. Since the activity of the cyclin B-CDK1 complex is regulated in part by phosphorylation, and CDC25B is also phosphorylated by the complex itself, the mRNA level expression appears to be inadequate for a complete description of the tested steroids on the regulatory network. In spite of the limitations of the applied PCR technique, it seems relevant that the expressions of all four regulating factors were significantly decreased, indicating that the intervention in the cell cycle machinery is likely to occur at upstream levels.

Stathmin or oncoprotein 18 is a highly conserved oncoprotein frequently overexpressed in cancer cells, which plays a crucial role in the early phase of mitosis, destabilizing the microtubules (Cassimeris, 2002). It is regulated by phosphorylation on four serine residues after turning off its destabilizing activity, and the cell can enter mitosis. Upon increased phosphorylation of stathmin, therefore, the accumulation of cells in the G2/M phase could be expected. This consideration is in agreement with the presented results and published findings. Treatment with an innovative formulation of paclitaxel resulted in a pronounced increase of gastric cancer cells in the G2/M phase and also the increased phosphorylation of stathmin (Zhang et al., 2013). Since this phosphorylation can be effected by a broad set of kinases, including CDK1 and CDK2, calmodulin-dependent protein kinase, and cAMP and cGMP dependent protein kinases, the exact enzyme responsible for the action of the presented steroids remains unclear.

Cancer selectivity is one of the most crucial parameters determining the decision as to the further development of a drug candidate. A viability assay and fluorescent staining on intact human fibroblast cells can certainly not be regarded as a complete toxicological evaluation. However, it is clearly promising that two of the four selected molecules (6f and 6g) exhibited higher calculated $\mathrm{IC}_{50}$ values against noncancerous than against malignant cells, and did not elicit substantial membrane damage up to $30 \mu \mathrm{M}$. A further one of the selected agents (5i) did not lead to $50 \%$ inhibition of fibroblast growth up to $30 \mu \mathrm{M}$, and the fourth (6h) proved selective for HeLa cells. 


\section{SUMMARY}

A diverse set of innovative compounds with steroidal skeleton bearing the pharmacophore triazole ring on different positions of ring $\mathrm{D}$ have been tested for antiproliferative activity. While $17 \alpha$-triazolyl derivatives exerted limited activities, $15-$ and 16-triazolyl steroids exhibited substantial actions deserving further investigations.

Some of them exhibited in vitro potencies comparable to that of the clinically utilized reference agent cisplatin. The most potent analogs were subjected to additional investigations in order to describe the mechanisms of their effects. Activation of the intrinsic pathway of apoptosis was evidenced by biochemical and morphological markers. Cell cycle blockade at the G2-M transition was additionally proved. The presented data demonstrate that estrone may be regarded as a suitable skeleton for the design of innovative antiproliferative drug candidates. 


\section{REFERENCES}

Alvarez R, Velazquez S, San-Felix A, Aquaro S, De Clercq E, Perno CF, Karlsson A, Balzarini J, Camarasa MJ: 1,2,3-Triazole-[2',5'-bis-O-(tert-butyldimethylsilyl)-beta-Dribofuranosyl]-3'-spiro-5"-(4"-amino-1",2"-oxathiole 2",2"-dioxide) (TSAO) analogues: synthesis and anti-HIV-1 activity. J Med Chem 37: 4185-94 (1994)

Anstead GM, Carlson KE, Katzenellenbogen JA: The estradiol pharmacophore: ligand structure-estrogen receptor binding affinity relationships and a model for the receptor binding site. Steroids 62: 268-303 (1997)

Banday AH, Shameem SA, Gupta BD, Kumar HM: D-ring substituted 1,2,3-triazolyl 20-keto pregnenanes as potential anticancer agents: Synthesis and biological evaluation. Steroids 75: 801-4 (2010)

Berényi A, Minorics R, Iványi Z, Ocsovszki I, Ducza E, Thole H, Messinger J, Wölfling J, Mótyan G, Mernyák E, Frank E, Schneider G, Zupkó I: Synthesis and investigation of the anticancer effects of estrone-16-oxime ethers in vitro. Steroids 78: 69-78 (2013)

Boutros R, Lobjois V, Ducommun B: CDC25 phosphatases in cancer cells: key players? Good targets? Nat Rev Cancer 7: 495-507 (2007)

Bray F, Jemal A, Grey N, Ferlay J, Forman D: Global cancer transitions according to the Human Development Index (2008-2030): a population-based study. Lancet Oncol 13: 790-801 (2012)

Brinkmann K, Kashkar H: Targeting the mitochondrial apoptotic pathway: a preferred approach in hematologic malignancies? Cell Death Dis 5: e1098 (2014)

Brodie A, Njar VCO: 17-Azolyl steroids useful as androgen synthesis inhibitors. United States Patent, Patent Number: 5,994,335 (1999).

Brunton L, Chabner B, Knollman B: Goodman and Gilman's The Pharmacological Basis of Therapeutics, Twelfth Edition. McGraw-Hill Education, 2011.

Buckle DR, Rockell CJ, Smith H, Spicer BA: Studies on 1,2,3-triazoles. 13. (Piperazinylalkoxy) [1]benzopyrano[2,3-d]-1,2,3-triazol-9(1H)-ones with combined H1-antihistamine and mast cell stabilizing properties. J Med Chem 29: 2262-7 (1986)

Cassimeris L: The oncoprotein 18/stathmin family of microtubule destabilizers. Curr Opin Cell Biol 14: 18-24 (2002)

Connolly PF, Jager R, Fearnhead HO: New roles for old enzymes: killer caspases as the engine of cell behavior changes. Front Physiol 5: 149 (2014) 
Ferguson AM, White LS, Donovan PJ, Piwnica-Worms H: Normal cell cycle and checkpoint responses in mice and cells lacking $\mathrm{Cdc} 25 \mathrm{~B}$ and $\mathrm{Cdc} 25 \mathrm{C}$ protein phosphatases. $\mathrm{Mol}$ Cell Biol 25: 2853-60 (2005)

Frank E, Schneider G: Synthesis of sex hormone-derived modified steroids possessing antiproliferative activity. J Steroid Biochem Mol Biol 137: 301-15 (2013)

Gabrielli BG, De Souza CP, Tonks ID, Clark JM, Hayward NK, Ellem KA: Cytoplasmic accumulation of cdc25B phosphatase in mitosis triggers centrosomal microtubule nucleation in HeLa cells. J Cell Sci 109 ( Pt 5): 1081-93 (1996)

Genin MJ, Allwine DA, Anderson DJ, Barbachyn MR, Emmert DE, Garmon SA, Graber DR, Grega KC, Hester JB, Hutchinson DK, Morris J, Reischer RJ, Ford CW, Zurenko GE, Hamel JC, Schaadt RD, Stapert D, Yagi BH: Substituent effects on the antibacterial activity of nitrogen-carbon-linked (azolylphenyl)oxazolidinones with expanded activity against the fastidious gram-negative organisms Haemophilus influenzae and Moraxella catarrhalis. J Med Chem 43: 953-70 (2000)

Gupta A, B. SK, Negi AS: Current status on development of steroids as anticancer agents. $J$ Steroid Biochem Mol Biol 137: 242-70 (2013)

Hofmeister H, Bittler D, Michna H, Habenicht U, Fritzemeier KH, Nishino Y: Antiandrogenic [3,2c]pyrazole and [3,2-d]triazole steroids. United States Patent, Patent Number: $5,389,624(1992)$

Kádár Z, Baji A, Zupkó I, Bartók T, Wölfling J, Frank É: Efficient approach to novel $1 \alpha-$ triazolyl-5 $\alpha$-androstane derivatives as potent antiproliferative agents. Org Biomol Chem 9: 8051-7 (2011a)

Kádár Z, Kovács D, Frank É, Schneider G, Huber J, Zupkó I, Bartók T, Wölfling J: Synthesis and in vitro antiproliferative activity of novel androst-5-ene triazolyl and tetrazolyl derivatives. Molecules 16: 4786-806 (2011b)

Kamal A, Reddy MK, Ramaiah MJ, Rajender, Reddy JS, Srikanth YV, Dastagiri D, Bharathi EV, Pushpavalli SN, Sarma P, Pal-Bhadra M: Synthesis and biological evaluation of estradiol linked pyrrolo[2,1-c][1,4]benzodiazepine (PBD) conjugates as potential anticancer agents. Bioorg Med Chem 19: 2565-81 (2011)

Kambhampati S, Rajewski RA, Tanol M, Haque I, Das A, Banerjee S, Jha S, Burns D, Borrego-Diaz E, Van Veldhuizen PJ, Banerjee SK: A second-generation 2Methoxyestradiol prodrug is effective against Barrett's adenocarcinoma in a mouse xenograft model. Mol Cancer Ther 12: 255-63 (2012) 
Kovács D, Mótyán G, Wölfling J, Kovács I, Zupkó I, Frank É: A facile access to novel steroidal 17-2'-(1',3',4')-oxadiazoles, and an evaluation of their cytotoxic activities in vitro. Bioorg Med Chem Lett 24: 1265-8 (2014)

Kumar S: Caspase function in programmed cell death. Cell Death Differ 14: 32-43 (2007)

Lee $\mathrm{CH}$, Lim H, Moon S, Shin C, Kim S, Kim BJ, Lim Y: Novel anticancer agent, benzyldihydroxyoctenone, isolated from Streptomyces sp. causes G1 cell cycle arrest and induces apoptosis of HeLa cells. Cancer Sci 98: 795-802 (2007)

Lee KR, Kozukue N, Han JS, Park JH, Chang EY, Baek EJ, Chang JS, Friedman M: Glycoalkaloids and metabolites inhibit the growth of human colon (HT29) and liver (HepG2) cancer cells. J Agric Food Chem 52: 2832-9 (2004)

Lindqvist A, Kallstrom H, Lundgren A, Barsoum E, Rosenthal CK: Cdc25B cooperates with Cdc25A to induce mitosis but has a unique role in activating cyclin B1-Cdk1 at the centrosome. J Cell Biol 171: 35-45 (2005)

Liu JF, Sang CY, Xu XH, Zhang LL, Yang X, Hui L, Zhang JB, Chen SW: Synthesis and cytotoxic activity on human cancer cells of carbamate derivatives of 4beta-(1,2,3triazol-1-yl)podophyllotoxin. Eur J Med Chem 64: 621-8 (2013)

Majeed R, Sangwan PL, Chinthakindi PK, Khan I, Dangroo NA, Thota N, Hamid A, Sharma PR, Saxena AK, Koul S: Synthesis of 3-O-propargylated betulinic acid and its 1,2,3triazoles as potential apoptotic agents. Eur J Med Chem 63: 782-92 (2013)

Mernyák E, Szabó J, Bacsa I, Huber J, Schneider G, Minorics R, Bózsity N, Zupkó I, Varga M, Bikádi Z, Hazai E, Wölfling J: Syntheses and antiproliferative effects of d-homoand d-secoestrones. Steroids 87: 128-36 (2014)

Mijatovic T, Van Quaquebeke E, Delest B, Debeir O, Darro F, Kiss R: Cardiotonic steroids on the road to anti-cancer therapy. Biochim Biophys Acta 1776: 32-57 (2007)

Mijatovic T, Kiss R: Cardiotonic steroids-mediated $\mathrm{Na}^{+} / \mathrm{K}^{+}$-ATPase targeting could circumvent various chemoresistance pathways. Planta Med 79: 189-98 (2013)

Minorics R, Szekeres T, Krupitza G, Saiko P, Giessrigl B, Wölfling J, Frank É, Zupkó I: Antiproliferative effects of some novel synthetic solanidine analogs on HL-60 human leukemia cells in vitro. Steroids 76: 156-62 (2011)

Minorics R, Bózsity N, Wölfling J, Mernyák E, Schneider G, Márki A, Falkay G, Ocsovszki I, Zupkó I: Antiproliferative effect of normal and 13-epi-D-homoestrone and their 3methyl ethers on human reproductive cancer cell lines. J Steroid Biochem Mol Biol 132: $168-75$ (2012) 
Molnár J, Ocsovszki I, Puskás L, Ghane T, Hohmann J, Zupkó I: Investigation of the antiproliferative action of the quinoline alkaloids kokusaginine and skimmianine on human cell lines. Curr Signal Transduct Ther 8: 148-55 (2013)

Mosmann T: Rapid colorimetric assay for cellular growth and survival: application to proliferation and cytotoxicity assays. J Immunol Methods 65: 55-63 (1983)

Peyrat JF, Brion JD, Alami M: Synthetic 2-methoxyestradiol derivatives: structure-activity relationships. Curr Med Chem 19: 4142-56 (2012)

Ribble D, Goldstein NB, Norris DA, Shellman YG: A simple technique for quantifying apoptosis in 96-well plates. BMC Biotechnol 5: 12 (2005)

Sahu JK, Ganguly S, Kaushik A: Triazoles: a valuable insight into recent developments and biological activities. Chin J Nat Med 11: 456-65 (2013)

Salvador JA, Pinto RM, Silvestre SM: Steroidal 5alpha-reductase and 17alphahydroxylase/17,20-lyase (CYP17) inhibitors useful in the treatment of prostatic diseases. J Steroid Biochem Mol Biol 137: 199-222 (2013)

Stenkvist B: Is digitalis a therapy for breast carcinoma? Oncol Rep 6: 493-6 (1999)

Tolomeo M, Simoni D: Drug resistance and apoptosis in cancer treatment: development of new apoptosis-inducing agents active in drug resistant malignancies. Curr Med Chem Anticancer Agents 2: 387-401 (2002)

Vermes I, Haanen C, Reutelingsperger C: Flow cytometry of apoptotic cell death. J Immunol Methods 243: 167-90 (2000)

Wölfling J, Hackler L, Mernyák E, Schneider G, Tóth I, Szécsi M, Julesz J, Sohár P, Csámpai A: Neighboring group participation. Part 15. Stereoselective synthesis of some steroidal tetrahydrooxazin-2-ones, as novel presumed inhibitors of human 5alphareductase. Steroids 69: 451-60 (2004)

Wölfling J, Oravecz EA, Ondre D, Mernyák E, Schneider G, Tóth I, Szécsi M, Julesz J: Stereoselective synthesis of some 17beta-dihydrooxazinyl steroids, as novel presumed inhibitors of 17alpha-hydroxylase-C17,20-lyase. Steroids 71: 809-16 (2006)

Xu T, Pang Q, Zhou D, Zhang A, Luo S, Wang Y, Yan X: Proteomic investigation into betulinic acid-induced apoptosis of human cervical cancer HeLa cells. PLoS One 9: e105768 (2014)

Zhang C, Awasthi N, Schwarz MA, Hinz S, Schwarz RE: Superior antitumor activity of nanoparticle albumin-bound paclitaxel in experimental gastric cancer. PLoS One 8: e58037 (2013) 
Zhou $\mathrm{CH}$, Wang Y: Recent researches in triazole compounds as medicinal drugs. Curr Med Chem 19: 239-80 (2012)

Zupkó I, Molnár J, Réthy B, Minorics R, Frank É, Wölfling J, Molnár J, Ocsovszki I, Topcu Z, Bitó T, Puskás GL: Anticancer and multidrug resistance-reversal effects of solanidine analogs synthetized from pregnadienolone acetate. Molecules 19: 2061-76 (2014) 


\section{ACKNOWLEDGEMENTS}

I would like to express my special thanks to Dr. István Zupkó és Dr. Róbert Gáspás, the heads of the Department of Pharmacodynamics and Biopharmacy, for providing me with the possibility to work in this department.

I am also grateful to my supervisor István Zupkó Ph.D for his help, advice support and encouragement.

I express my gratitude for Prof. Dr. János Wölfling and his colleagues, Department of Organic Chemistry, University of Szeged for the design and synthesis of the steroid compounds.

I express my gratitude for all my colleagues and co-authors in the Department of Pharmacodynamics and Biopharmacy for creating a supportive and pleasant athmosphere.

I am deeply grateful for my family and my friends for their patience and support. 